\title{
NAHDLATUL ULAMA (NU) DAN KONTRIBUSINYA DALAM MEMPERJUANGKAN KEMERDEKAAN DAN MEMPERTAHANKAN NEGARA KESATUAN REPUBLIK INDONESIA (NKRI)
}

\author{
Amin Farih \\ Universitas Islam Negeri (UIN) Walisongo Semarang \\ e-mail: amin.farih@walisongo.ac.id
}

\begin{abstract}
Religious mission of Nahdlatul Ulama (NU) in consolidating power against Dutch colonialism is a part of the struggle of $\mathrm{NU}$ for defending religious ideology and nationalism, as a form of patriotism (hubb al-wațan). NU had to expell the Dutch colonialists because it is a religious teaching. The law had already become a decision of the religious leaders (kiai) of NU, which ultimately rise "the resolution of jihad". This resolution became a powerful principle of student-army who are combined both in of Hizbullāh and Sabilillāh. Some views of NU that the principles of equality, justice, removing all forms of exploitation and colonization, are the spirit NU to maintain consistency of state sovereignty, strengthen the nation integrity. Applying historical method, this study described the role and contribution of NU in fighting against Dutch colonialism, for independence and defend the nation's sovereignty within the framework of the unitary state of Indonesia (NKRI).

Dakwah Nahdlatul Ulama (NU) untuk menghimpun kekuatan melawan penjajahan Belanda merupakan bagian dari perjuangan NU untuk mempertahankan ideologi agama dan nasionalismenya sebagai bentuk cinta tanah air (hubb al-wațan). Peran NU dalam mengusir penjajah Belanda merupakan anjuran agama yang wajib dijalankan. Hukum tersebut sudah menjadi keputusan para kiai NU, yang akhirnya melahirkan "resolusi jihad". Resolusi ini menjadi pegangan ampuh para pasukan santri yang tergabung dalam laskar Hizbullāh maupun laskar Sabīillāh. Demikian juga pandangan NU bahwa prinsip-prinsip kesetaraan, keadilan, membuang segala bentuk eksploitasi dan penjajahan, merupakan spirit NU untuk menjaga konsistensi kedaulatan negara, memperkokoh integritas bangsa dan negara. Dengan pendekatan sejarah, penelitian ini menguak peran dan kontribusi NU dalam melawan penjajahan Belanda, merebut kemerdekaan serta mempertahankan kedaulatan bangsa dalam bingkai negara kesatuan Indonesia (NKRI).
\end{abstract}

Keywords: NU; Nahdlatul Ulama; hịizbullāh; sabīlillāh; independence; NKRI 


\section{A. Pendahuluan}

Nahdlatul Ulama (NU) sejak kelahirannya merupakan wadah perjuangan untuk menentang segala bentuk penjajahan dan merebut kemerdekaan negara Republik Indonesia dari penjajah Belanda dan Jepang, sekaligus aktif melakukan dakwah-dakwahnya untuk senantiasa menjaga kesatuan negara Republik Indonesia dalam wadah NKRI. Bagaimana NU dalam peranannya yang begitu besar dalam memperjuangkan kemerdekaan Indonesia, mempertahankan keutuhan NKRI dapat dilihat atas latar belakang lahirnya ormas terbesar di dunia Nahdlatul Ulama (NU). Paling tidak ada tiga alasan besar yang melatarbelakangi lahirnya Nahdlatul Ulama 31 Januari 1926, yaitu Pertama, motif agama. Kedua, motif mempertahankan paham Ahlu al-Sunnah wa 'l-Jamā'ah, dan ketiga, motif nasionalisme. $^{1}$

Motif nasionalisme timbul karena NU lahir dengan niatan kuat untuk menyatukan para ulama dan tokoh-tokoh agama dalam melawan penjajahan. Semangat nasionalisme itu pun terlihat juga dari nama Nahdlatul Ulama itu sendiri yakni "Kebangkitan Para Ulama”. NU pimpinan Hadhratus Syaikh KH. Hasyim Asy'ari sangat nasionalis. Sebelum RI merdeka, para pemuda di berbagai daerah mendirikan organisasi bersifat kedaerahan, seperti Jong Cilebes, Pemuda Betawi, Jong Java, Jong Ambon, Jong Sumatera, dan sebagainya, akan tetapi kiai-kiai NU justru mendirikan organisasi pemuda bersifat nasionalis. Pada tahun 1924 para pemuda pesantren mendirikan Shubban al-Wațān (Pemuda Tanah Air). Organisasi pemuda itu kemudian menjadi Ansor Nahdlatoel Oelama (ANO) yang salah satu tokohnya adalah Kiai Muhammad Yusuf Hasyim. Selain itu dari rahim Nahdlatul Ulama (NU) lahir laskar-laskar

\footnotetext{
${ }^{1}$ Motif nasionalisme adalah diantara tiga motif lahirnya NU, diantaranya yaitu Pertama, Motif agama karena Nahdlatul Ulama lahir atas semangat menegakkan dan mempertahankan Agama Allah SWT di Nusantara, meneruskan perjuangan Walisongo. Terlebih Belanda-Portugal tidak hanya menjajah Nusantara, tapi juga menyebarkan agama Kristen-Katolik dengan sangat gencarnya. Mereka membawa para misionaris-misionaris Kristiani ke berbagai wilayah. Kedua, motif mempertahankan paham Ahlu al-Sunnah wa al-Jamä'ah, karena NU lahir untuk membentengi umat Islam khususnya di Indonesia agar tetap teguh pada ajaran Islam Ahlu al-sunnah wa al-Jamā'ah (Para Pengikut Sunnah Nabi, Sahabat dan Ulama Salaf Pengikut Nabi-Sahabat), sehingga tidak tergiur dengan ajaran-ajaran baru yang tidak dikenal pada zaman Rasul-Sahabat-Salafus Shaleh/ajaran ahli bid'ah yaitu pembawa ajaran-ajaran bid'ah yang sesat (bid'ah madzmumah). Lihat, Choirul Anam, Pertumbuhan dan Perkembangan NU(Surabaya: Bisma Satu Press, 1998), h. 36.
} 
perjuangan fisik, di kalangan pemuda muncul laskar-laskar Hizbullāh (Tentara Allah) dengan panglimanya KH. Zainul Arifin seorang pemuda kelahiran Barus Sumatera Utara tahun 1909, dan di kalangan orang tua Sabilillāh (Jalan menuju Allah) yang di komandoi KH. Masykur, laskar-laskar NU di atas siap berjuang jihad menegakkan agama dan bangsa, mengusir para penjajah Belanda dan Jepang untuk merebut kemerdekaan negara kesatuan Republik Indonesia. ${ }^{2}$

Perjuangan yang dilakukan oleh Nahdlatul Ulama (NU) dengan upaya yang kuat menggerakan para ulama, santri dan umatnya untuk bangkit menghimpun kekuatan melawan pemerintahan asing yang dianggap kafir, merupakan bukti sejarah yang tidak dapat dipungkiri. Bahkan menurut hitungan rasional kemerdekaan negara Indonesia ini tidak akan pernah terwujud, mengingat rakyat Indoneisa pada saat itu merupakan rakyat yang miskin, serba kekurangan, untuk makan saja masih sulit akibat kejamnya penjajahan, demikian juga minimnya persenjataan yang dimiliki oleh pasukan dan relawan pejuang rakyat kita, apabila dibandingkan dengan persenjataan yang dimiliki oleh penjajah Belanda. Akan tetapi berkat motivasi para ulama kita termasuknya adalah ulama NU yang berupaya mentranspormasi gerakan-gerakan yang bersifat spontanitas kepada mekanik atau organik dari doa dan wirid-wirid yang diberikan oleh ulama-ulama NU (bisa berupa asmā', hizb, dhikir, șalawāt dan lain sebagainya) menjadi sebuah sugesti besar pensakralan dan kekuatan besar untuk melawan peperangan melawan penjajah, maka dengan sugesti yang kuat

\footnotetext{
2Perjuanagn NU dalam melawan penjajah tidak hanya dalam masalah jihad, tetapi perjuangan NU juga menentang terhadap semua kebijakan politik yang tidak menguntungkan pribumi, ada beberapa kebijakan yang ditentang oleh NU atas ketidak adilan kolonial Belanda pada beberapa masalah, diantaranya: (1) Masalah Pendidikan; Belanda melakukan ketidakadilan dalam hal administrasi sekolah yang mengintimidasi terhadap eksistensi sekolah, pesantren, guru sekolah dan guru pesantren untuk tidak berkembang dan bahkan kalo bisa mati dengan sendirinya dengan cara melakukan regulasi pendidikan yang merugikan pada sekolah, pesantren dan gurunya (2) Masalah Peradilan Agama; Belanda membatasi gerak langlah peradilan agama untuk tidak mengurusi masalah perdata Islam, dan wewenang tersebut dikembalikan pada sistem adat istiadat, hukum adat kembali diberlakukan di Jawa, Madura dan Kalimantan Selatan, bukan semata-mata hukum adat yang menjadi soal, melainkan penggrogotan kekuasaan Peradilan Agama yang merupakan lambang wewenang kaum Muslimin sudah dirusak dan bahkan kalo perlu dimatikan. (3) Masalah Undang-Undang Perkawinan; Undangundang perkawinan diintervensi penuh oleh Kolonial Belanda, dan bahkan UU tentang perkawinan, keleluasaan mengutarakan kritik terhadap agama Islam dan meminta supaya pengetahuan keagamaan para pegawai yang ada didalamnya diawasi secara ketat dan diperlakukan tidak adil. Lihat, Lukman Hakim, dkk. 2004. Perlawanan Islam Kultural: Relasi Asosiatif Pertumbuhan Civil Society dan Doktrin Aswaja NU (Surabaya: Pustaka Eureka Berger, Peter L. 1991), h. 97.
} 
ini perjuangan para ulama bisa menghantarkan ke sebuah kemerdekaan berkat rahmat Allah. ${ }^{3}$

Umat Islam di bawah komando para ulama telah memberikan warna dan sangat yang terang dalam sejarah perjuangan pergerakan kemerdekaan negara Indonesia, utamanya dalam perlawanan menetang penjajahan Belanda, merebut dan mempertahankan kemerdekaan pada masa revolusi fisik saat seluruh bangsa mempertaruhkan hidup dan mati untuk tetap tegaknya kemerdekaan Indonesia. Begitu mendalamnya torehan sejarah yang dipahat umat Islam sepanjang masa Imperialisme di bumi Nusantara ini, sehingga kemanapun kita mencoba melacak jejak perjuangan dimasa penjajahan maka senantiasa pula akan kita temukan pijaran api semangat perjuangan Islam dimana-mana. Mempelajari tentang sejarah perjuangan perlawanan umat Islam Indoneisa melawan penjajah Belanda, maka dalam perjalanannya akan kita temukan periode dimana bermunculan berbagai macam lembaga atau organisasi sosial dan keagamaan yang berjuang mewadahi kekuatan ummat sebagai salah satu potensi yang menopang untuk tegaknya kedaulatan negara. Perjuangan umat Islam dan organisasi yang mewadahinya dapat dilihat mulai dari lahirnya SDI (Serikat Dagang Indonesia) tahun 1911 M yang kemudian pada tanggal 10 September 1912 menjadi wadah Serikat Islam (SI), ${ }^{4}$ kemudian muncullah organisasi Muhamadiyyah tahun 1912, kemudian disusul NU pada tahun 1926 di bawah pimpinan oleh KH. Hasyim Asy'ari, dimana NU tampil

\footnotetext{
${ }^{3}$ Ahmad Mansur Suryanegara, Api Sejarah: Mahakarya Perjuangan Ulama dan Santri dalam Menegakkan Negara Kesatuan Republik Indonesia (Bandung: Salmadani, 1433/2012), h.36. Lihat juga: Slamet Efendi, Dinamika Kaum Santri Menelusuri Jejak dan Pergolakan Internal NU Uakarta: Rajawali Press, 1983), h. 38.

${ }^{4}$ Pada perkembangan selanjutnya, SI mendapat simpati umat Islam secara luas tidak hanya di Surakarta. Bergabungnya HOS. Tjokroaminoto (1882-1934) dalam SI menambah kekuatan dan menarik simpati massa. Tjokroaminoto yang kharismatik dan berani mengkritik penjajah menjadi daya tarik tersendiri yang tidak dimiliki oleh organisasi pada masanya. Ditambah lagi kekuatan pimpinan SI tidak hanya ada pada diri Tjokroaminoto, melainkan juga ada pada diri H. Agoes Salim (1884-1954), Abdoel Moeis (1890-1959) dan Wignjadisastra. Dengan jajaran pimpinan yang kharismatik dan basis massa yang luas, SI semakin berani mengkritik penjajah dengan mengadakan National Congres Central Sarekat Islam yang pertama di gedung Concordia atau gedung Merdeka di Bandung pada 17-24 Juni 1916. Dalam kongres ini SI mempelopori penggunaan istilah nasional dalam masyarakat luas, dan menuntut Indonesia merdeka dengan istilah pemerintahan sendiri atau Zelf Bestuur. Maka tak heran jika Kahin menyatakan bahwa Sarekat Islam merupakan gerakan politik pertama di Indonesia. Gerakan kebangkitannya sangatlah menakjubkan bagi umat Islam dan tentu menjadi ancaman berbahaya bagi penjajah Belanda. Lihat: Ahmad Mansur Suryanegara, A.P.E Korver, Sarekat Islam Gerakan Ratu Adil, (Jakarta: Grafiti, 1985), h. 353-394.
} 
sebagai pionir dan perintis kemerdekaan semenjak masa jauh sebelum Indonesia merdeka dan merekapun ikut menjadi bagian pendiri dari negara Republik Indonesia ini. ${ }^{5}$

Pada masa penjajahan Jepang menguasai Indonesia, arena perjuangan $\mathrm{NU}$ justru semakin melebarkan sayapnya. Sikap anti penjajah yang memang sudah pembawaannya, menyebabkan antisipasi terhadap perkembangan keadaan yang menyangkut keselamatan negara semakin ditingkatkan, lebih-lebih lagi ketika kehadiran tentara sekutu dan NICA (Belanda) mendarat di Indonesia dan dimana-mana melakukan teror untuk merobohkan negara Republik Indonesia yang masih sangat mudah pada waktu itu. Kondisi yang sangat genting seperti ini menjadikan NU di bawah kepemimpinan KH. Hasyim Asy'ari (yang merasa mempunyai andil dalam proses-proses perumusan kemerdekaannya) terdorong untuk mengeluarkan sebuah fatwa terkenal dengan nama "Resolusi Jihad" pada tanggal 22 Oktober 1945. Sebuah kebulatan tekad yang isinya menwajibkan kepada seluruh umat Islam baik pria maupun wanita mengangkat senjata melawan kolonialisme dan imperialisme yang mengancam keselamatan negara Republik Indonesia. Peran NU dan keterlibatannya yang besar hampir seluruh warga NU untuk menjalankan jihad mengusir penjajah ini, pada gilirannya bisa mendorong kehendak kuat bagi negara dan NU untuk menuntut peranannya yang lebih besar dalam perjuangan selanjutnya (mengisi kemerdekaan) yang tentunya berlandaskan pada semangat nilainilai Resolusi Jihad dengan bentuk aktualisasi yang lain. ${ }^{6}$

\footnotetext{
${ }^{5}$ Beberapa organisasi yang berdiri di awal abad ke-20 seperti SDI, SI, PERSIS dan Muhamadiyyah lebih bercorak modernis dan bertujuan sebagai pemurnian akidah dan ibadah dari bid'ah khurafat dan takhayyul. Gerak organisasi itu pun dipengaruhi oleh pemikiran Pan-Islamisme yang ada di Mesir. Maka, pada tahun 1926, dengan prakarsa KH. Hasyim Asy'ari, berdirilah Nahdlatul Ulama pada 31 Januari 1926 di Surabaya. NU berdiri untuk mempertahankan dan menyebarkan pemahaman kaum tradisionalis yang masih banyak dianut oleh masyarakat pedesaan dan kalangan pesantren. Dengan akar historis yang kuat dan luas, NU tidak kalah cepat dalam menerima respon masyarakat bukan saja di Jawa, namun juga di Sumatera dan Kalimantan. Dengan pemahaman yang tradisionalis dan pengaruh pesantren yang kuat, NU bahkan menjadi organisasi terbesar dibandingkan Muhammadiyah dan PERSIS. Maka tak heran jika NU mampu mendirikan partai sendiri setelah sebelumnya terjadi pergeseran dalam tubuh Masyumi. Lihat: Ahmad Mansur Suryanegara, Menemukan Sejarah: Wacana Pergerakan Islam di Indonesia (Bandung: Mizan, 1996), h. 340-347.

'Akhirnya beberapa hari kemudian "Resolusi Jihad NU" ini menjadi Resolusi umat Islam Indonesia yang dikumandangkan hampir di seluruh tanah Jawa dan gerakan ini menjadi salah satu sumber yang memberikan motivasi kuat pada ribuan pemuda pejuang Islam yang tergabung dalam laskar-laskar rakyat yang sangat aktif melibatkan diri seperti dalam pertempuran 10 Nopember 1945 di Surabaya,
} 
Arti penting lain pembentukan NU sebagai sebuah organisasi adalah berkaitan dengan wawasan kebangsaan (nasionalisme) yang selalu dijadikan sebagai salah satu dasar perjuangannya selama ini. Wawasan kebangsaan yang dimiliki oleh NU tersebut dapat dilihat pada setiap langkah dan kebijakan NU sejak dulu hingga sekarang yang selalu mengutamakan kepentingan bangsa dan negara. Perjuangan NU ini berkobar terus mulai sejak penjajahan Belanda menyerbu Indonesia sampai penjajahan Jepang. ${ }^{7}$ Oleh karenanya tujuan NU membentuk sebuah perkumpulan adalah untuk membentuk organisasi perjuangan yang senantiasa menentang segala bentuk penjajahan untuk merebut kemerdekaan dan sekaligus menjaga kesatuan negara Republik Indonesia dalam wadah NKRI.

Dari latar belakang ini, maka peneliti ingin membahas tentang kontribusi NU dalam perjuangan kemerdekaan negara Republik Indonesia dan pandangan NU dalam mempertahankan kadaulatan RI dalam bingkai negara kesatuan Republik Indonesia. Permasalahan yang diangkat dalam penelitian ini adalah: 1) Mengapa NU mempunyai andil dalam kemerdekaan dan mempertahankan NKRI; 2) Bagaimana bentuk andil ulama NU dalam merebut kemerdekaan dan mempertahankan NKRI; 3) Kontribusi apa yang diberikan oleh ulama NU dalam merebut kemerdekaan dan mempertahan NKRI. Atas dasar latar

pertempuran Palagan Ambara, pertempuran lima hari di Semarang, Lautan Api dan pertempuranpertempuran di Bandung lainya yang tidak tercatata dalam sejarah. Lihat: Sukidi Mulyadi, "Violence under The Banner of Religion: The Case of Laskar Jihad and Laskar Kristus," Jurnal Studia Islamika, Vol. 10, No. 1, 2003, h. 77-79. Lihat juga: Lukman Hakim, Perlawanan Islam Kultural: Relasi Asosiatif Pertumbuhan Civil Society dan Doktrin Aswaja NU(Surabaya: Pustaka Eureka Berger, Peter L 1991), h. 53.

${ }^{7}$ Walalupun pada masa penjajahan Jepang, NU memilih sikap lunak dan diplomatis, namun kelunakan NU ini tetap bertujuan untuk merebut kemerdekaan RI, kelunakan ini bertujuan untuk menarik simpati ke Jepang agar NU dapat membentuk gerakan-gerakan perjuangan kepemerdekaan dengan cara memanfaatkan isu kolaborasi dengan pemerintahan Jepang. Gerakan NU pada masa Jepang tergabung dalam gerakan-gerakan yang dibuat oleh penjajah Jepang diantaranya: Pertama, TIGA A, gerakan Tiga A ini mempunyai semboyan: Nippon Pelindung Asia, Nippon Cahaya Asia, dan Nippon Pemimpin Asia. Dipimpin oleh Syamsuddin SH. Tahun 1943, dibubarkan karena tidak mendapat simpati dari rakyat dan diganti Putera. Kedua, gerakan PUTERA (Pusat Tenaga Rakyat), Putera dibentuk tahun 1943 dipimpin oleh empat serangkai yaitu Bung Karno, Bung Hatta, Ki Hajar Dewantara, dan Kiai Haji Mas Mansyur. Tujuan dibentuk Putera yaitu untuk membantu Jepang dalam setiap perang yang dilakukannya. Tetapi Oraganisasi Putera merupakan bumerang bagi Jepang sebab anggota Putera memiliki nasionalisme yang tinggi. Ketiga, Gerakan PETA (Pembela Tanah Air), Peta merupakan organisasi bentukan Jepang yang terdiri dari pemuda Indonesia. Organisasi ini disebut pula Giyugun. Mereka mendapat latihan militer dari Jepang. Tujuannya untuk memenuhi kepentingan peperangan Jepang di Lautan Pasifik. Lukman Hakim, dkk. 2003. Kebangkitan Agama Menantang Politik Dunia (Yogyakarta: Ar-Ruzz Hartono, 2003), h. 77 
belakang dan rumusan masalah tersebut, maka tujuan penelitian ini adalah: a) untuk mengkaji dan menganalisis bagaimana peran NU dalam merebut kemerdekaan RI dan mempertahankan NKRI; b) untuk mengkaji dan menganalisis sejauhmana kontribusi $\mathrm{NU}$ dalam mempertahankan kesatuan negara Indonesia dalam bingkai NKRI.

Metode penelitian ini menggunakan metode sejarah, metode sejarah dapat diartikan sebagai cara atau prosedur yang sistematis dalam merekonstruksi masa lampau. ${ }^{8}$ Pendekatan sejarah ini paling tidak terdapat empat langkah metode sejarah yang penulis sajikan yaitu: 1) Heuristik, yakni kegiatan mencari dan menemukan sumber yang diperlukan. Peneliti akan mengambil sumber primer dan sekunder terkait dengan sumber-sumber sejarah yang terdiri atas jurnal ilmiah, arsip, dokumen, buku, majalah, surat kabar, yang ada hubungannya dengan peran NU dalam merebut kemerdekaan dan mempertahankan kesatuan negara Republik Indonesia. 2) Kritik, langkah kedua yang peneliti lakukan adalah pengerjaan studi sejarah yang akademis atau kritis terhadap fakta-fakta yang telah teruji. Oleh karena itu, data-data yang peneliti peroleh melalui tahapan heuristik terlebih dahulu peneliti melakukan kritik sehingga diperoleh fakta-fakta yang seobjektif mungkin. Kritik tersebut berupa kritik tentang otentitasnya (kritik ekstern) ${ }^{9}$ maupun kritik tentang kredibilitas isinya (kritik intern). ${ }^{10}$ Metode ini dimaksudkan agar peneliti memperoleh fakta yang

\footnotetext{
8Metode penelitian sejarah adalah metode atau cara yang digunakan sebagai pedoman dalam melakukan penelitian peristiwa sejarah dan permasalahannya. Dengan kata lain, metode penelitian sejarah adalah instrumen untuk merekonstruksi peristiwa sejarah (history as past actuality) menjadi sejarah sebagai kisah (history as written). Lihat: Taufik Abdullah dan Abdurrachman Surjomihardjo, Ilmu Sejarah dan Historiografi: Arah dan Perspektif(Jakarta: Gramedia, 1984), h. xv-xx.

${ }^{9}$ Kritik ekstern terhadap sumber lisan kalau memang menggunakan teknik wawancara dilakukan terhadap para informan yang akan diwawancarai. Informan harus memiliki kemampuan untuk memberikan keterangan yang sebenarnya. Hal itu dapat dilihat dari keterlibatannya atas suatu peristiwa, serta tingkat keintelektualannya. Caranya antara lain dengan jalan meminta keterangan kepada para informan tentang keterlibatan informan lainnya atas peristiwa tersebut. Lihat dalam; Louis Gostchalck, Mengerti Sejarah, terj. Nugroho Notosusanto (Jakarta: Universitas Indonesia Press, 1983), h. 32.

${ }^{10}$ Kritik intern terhadap sumber tertulis perlu dilakukan agar tidak terperangkap kepada dokumen palsu. Oleh karena itu perlu dipertanyakan tentang otentik atau tidak sejatinya suatu sumber. Juga perlu diketahui tentang asli dan utuhnya sumber-sumber. Kalau sebuah dokumen tidak lagi utuh atau cacat, seorang sejarawan harus mengadakan restorasi teks agar dokumen tersebut kembali utuh dalam arti isi yang terkandung dapat diterima secara ilmiah. Untuk itu diperlukan berbagai ilmu bantu sejarah yang dapat memberikan penjelasan yang logis atas dokumen tersebut, seperti arkeologi, filologi, dan sebagainya. Kritik intern terhadap sumber tertulis terutama dilakukan dengan jalan melihat kompetensi, atau kehadiran pengarang terhadap waktu atau peristiwa. Kepentingan pengarang, sikap berat sebelah
} 
dapat mengantarkan kepada kebenaran ilmiah. 3) Interpretasi, adalah penafsiran fakta untuk ditulis hingga ada artinya, ada maknanya, fakta-fakta tersebut dilihat hubungannya, keterkaitan, disesuaikan dengan fokus, hal terkait, dan kegunaannya hinga betul-betul layak dijadikan bahan dasar penulisan sejarah yang terkait dengan peran NU dalam merebut kemerdekaan dan mempertahankan kesatuan negara Republik Indonesia. 4) Historiografi, tahap terakhir dari kegiatan penelitian ini saya melakukan rekaman tentang segala sesuatu yang dicatat sebagai bahan pelajaran tentang perilaku yang baik. Sesudah menentukan judul, mengumpulkan bahan-bahan atau sumber serta melakukan kritik dan seleksi, maka mulailah saya menuliskan kisah sejarah tentang peran ulama NU dalam kemerdekaan dan mempertahankan konsep NKRI serta paparan hasil penelitian tentang kebenaran bukti sejarah tentang peran NU dalam merebut kemerdekaan dan mempertahankan Negara Kesatuan negara Republik Indonesia. ${ }^{11}$

\section{B. Dasar Perjuangan Nahdlatul Ulama (NU) dalam Mewujudkan Kemerdekaan Negara Indonesia}

Nahdlatul Ulama (NU) dalam setiap langkahnya selalu mengutamakan kepentingan bangsa, negara dan senantiasa dilandasi oleh dasar sharīat Islam dan nilai-nilai ke-Islam-an, juga didasari atas nilai-nilai ke-Indonesia-an dan semangat nasionalisme yang tinggi, hal ini dapat kita lihat bagaimana latar belakang Nahdlatul Ulama ini lahir, bagaimana peranannya yang begitu besar dalam memperjuangkan kemerdekaan Indonesia dan mempertahankan keutuhan NKRI. NU pimpinan KH. Hasyim Asy'ari sangat menjunjung tinggi nilainilai kebangsaan, nasionalisme yang berdasarkan atas syari'at Islam 'alā Ahl alSunnah wal al-Jamä'ah. ${ }^{12}$ Peranan Nahdlatul Ulama pada masa penjajahan

serta motif pengarang, juga sangat perlu untuk diketahui guna menentukan kredibilitas isi tulisan. Sedangkan terhadap sumber tertulis berupa dokumen, dilakukan dengan melihat segi semantik, hermeneutik, dan pemahaman terhadap historical mindedness. Lihat: Aminudin Kasid, Pengantar Ilmu Sejarah, (Semarang, UNESS Press, 2015), h.11. Lihat juga: Nugroho Notosusanto, Teori Sejarah dan Perannya dalam Rangka Study Sejarah, (Jakarta: UI Press, 1978), h. 36.

${ }^{11}$ Robert Bag, Bikten, Qualitative Research For Education; An Introduction to Theory and Methods, (Boston: Allyn and Bocon, 1982), h. 56 lihat juga teori induksi analitik dalam bukunya Noeng Muhadjir, Penelitian Kualitatif, h. 99.

${ }^{12}$ Diantara motif pendirian NU adalah untuk mempertahankan paham Ahlu al-Sunnah wal alJamā’ah. NU lahir untuk membentengi umat Islam khususnya di Indonesia agar tetap teguh pada ajaran 
Belanda dapat dilihat pada keputusan Muktamar Nahdlatul Ulama ke-2 di Banjarmasin pada tahun 1936, yang memutuskan bahwa kedudukan Hindia Belanda (Indonesia) sebagai Dār al-Salām, yang menegaskan keterikatan Nahdlatul Ulama dengan nusa-bangsa. Meskipun disadari peraturan yang berlaku tidak menggunakan Islam sebagai dasarnya, akan tetapi Nahdlatul Ulama tidak mempersoalkan, karena yang terpenting adalah umat Islam dapat melaksanakan syariat agamanya dengan bebas dan aman. Pandangan Nahdlatul Ulama bahwa perjuangan jihad ulama dalam mengusir penjajah Belanda sebenarnya adalah tuntunan ajaran agama Islam yang harus dilaksanakan setiap umat-Nya sebagai bentuk manivestasi rasa syukur terhadap Allah yang Mahakuasa. Jihad yang dilakukan oleh ulama dan santrinya ialah jihad membela tanah air, sebagai bentuk cinta tanah air (hubb al-wațan) yang dimaknai sebagai jihād fi sabïlillāh. Karena upaya mempertahankan dan menegakkan negara Republik Indonesia dalam pandangan hukum Islam merupakan bagian dari kewajiban agama yang harus dijalankan umat Islam. ${ }^{13}$

Menurut KH. Hasyim Asy'ari, jihad merupakan satu amalan besar dan penting dalam Islam dengan keutamaannya yang sangat banyak sekali, tentunya menjadi kewajiban seorang muslim untuk melaksanakanya bila suatu saat diserang oleh orang kafir. Oleh karena itu menurut KH. Hasyim Asy'ari dalam konteks melawan penjajah Belanda, memberikan fatwa jihad mempertahankan tanah air Indonesia hukumnya wajib atas seluruh orang yang berada di wilayah negara Indonesia yang diserang musuh penjajah kafir Belanda, sebagaimana firman Allah dalam surat al-Baqarah:

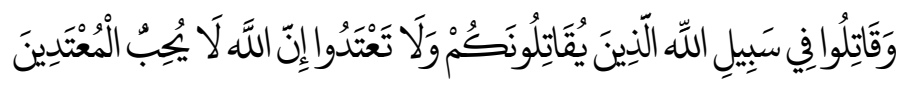

Islam Ahlu al-sunnah wal al-jamāah, sehingga tidak tergiur dengan ajaran-ajaran baru. Pembawa ajaran-ajaran bid'ah yang sesat, keberadaan NU adalah ormas yang membawa konsep tawassut, tawazun, ta'adul dan tasamuh, sehingga kelahiran NU mempunyai tujuan untuk bersikap moderat dalam memahami agama sesuai dengan ajaran Ahlu al-sunnah wal al-jamä’ah. Lihat dalam buku: Drs. Choirul Anam, Pertumbuhan dan Perkembangan NU (Surabaya: Bisma Satu Press, 1998), h. 36. Lihat, KH. Achmad Siddiq, Islam, Pancasila dan Ukhuwah Islamiyyah (Jakarta: Lajnah wa al-Nars PBNU dan Penerbit Sumber Barokah, 1985), h. 18-21.

${ }_{13}^{13}$ Sebagaimana dijelaskan dalam buku sejarah peran Ulama NU dalam mengusir penjajah Belanda merupakan anjuran agama yang waijb dijalankan. Hukum tersebut sudah menjadi keputusan para kiai, yang akhirnya melahirkan "resolusi jihad". Resolusi ini menjadi pegangan ampuh para pasukan santri yang tergabung dalam laskar hizbullāh maupun laskar sabilillāhh, Lihat, Zainul Milal Bizawie, Laskar Ulama dan santrinya \& Resolusi Iihad; Garda Depan Menegakkan Indonesia 1945-1949 (Jakarta: Pustaka Compass Tangerang, 1998), h. 208. 
“Dan perangilah di jalan Allah orang-orang yang memerangi kamu, (tetapi) janganlah kamu melampaui batas." ${ }^{14}$

Dari dasar al-Qur'an ini maka Nahdlatul Ulama (NU) bersepakat bahwa jihad memerangi penjajah Belanda wajib hukumnya, disinilah pimpinan NU terutama KH. Hasyim Asyari sebagai komandan organisasi NU ikut mendukung upaya kemerdekaan dengan menggerakkan rakyat melalui fatwa jihad, Hasilnya pada 22 Oktober 1945, KH. Hasyim Asy'ari dan sejumlah ulama di kantor NU Jawa Timur mengeluarkan keputusan resolusi jihad itu. Karena itulah KH. Hasyim Asy'ari diancam hendak ditangkap Belandal, namun KH. Hasyim Asy'ari tidak bergeming, dia memilih bertahan mendampingi laskar Hizbullāh dan Sabilillāh melawan penjajah. Bahkan ketika Bung Tomo meminta KH. Hasyim mengungsi dari Jombang, Kiai Hasyim berkukuh bertahan hingga titik darah penghabisan, hingga muncul sebuah kaidah (rumusan masalah yang menjadi hukum) populer di kalangan kelompok tradisional NU; hubbu al-wațan min alimān (mencintai tanah air adalah bagian dari iman). ${ }^{15}$

Semangat dakwah anti kolonialisme sudah melekat pada diri KH. Hasyim sejak belajar di Makkah, ketika jatuhnya dinasti Ottoman di Turki. KH. Hasyim pernah mengumpulkan kawan-kawannya, lalu berdoa di depan Multazam, berjanji menegakkan panji-panji keislaman dan melawan berbagai bentuk penjajahan. ${ }^{16}$ Sikap anti penjajahan juga sempat membawa KH. Hasyim masuk bui ketika masa penjajahan Jepang. Waktu itu, kedatangan Jepang disertai kebudayaan Saikerei yaitu menghormati Kaisar Jepang Tenno Heika dengan

\footnotetext{
${ }^{14}$ QS. al-Baqarah [2]: 190.

15Pada masa penjajahan Belanda, KH. Hasyim Asy'ari senantiasa berkomunikasi dengan tokohtokoh muslim dari berbagai penjuru dunia untuk melawan penjajahan. Misalnya dengan Pangeran Abdul Karim al-Khatthabi (Maroko), Sultan Pasha Al-Athrasi (Suriah), Muhammad Amin al-Husaini (Palestina), Dhiyauddin al-Syairazi, Muhammad Ali, dan Syaukat Ali (India), serta Muhammad Ali Jinnah (Pakistan). Akibat fatwa ini yang kemudian dikenal sebagai resolusi jihad melawan penjajah Belanda pada 22 Oktober 1945, yang menghasilkan poin-poin keputusan: (1) kemerdekaan bagi negara Indonesia (2) Republik Indonesia sebagai satu-satunya pemerintahan yang sah (3) Musuh Republik Indonesia yaitu Belanda (4) umat Islam terutama anggota NU harus mengangkat senjata melawan penjajah Belanda. (5) kewajiban ini bagi setiap muslim yang tinggal dalam radius $94 \mathrm{~km}$. Akibat fatwa itu, meledaklah perang di Surabaya pada 10 November 1945. Lihat: Ahmad Mansur Suryanegara, Api Sejarah: Mahakarya Periuangan Ulama dan Santri ...., h. 340-347, lihat juga: M. Adnan, Resolusi Jihad dalam Peristiwa 10 November (Surabaya: Jawa Pos, 1999), h. 9.

16Semangat itu dia bawa tatkala kembali ke Indonesia dan dia tularkan kepada anaknya Wahid Hasyim. Kelak, Wahid Hasyim dipercaya menjabat sebagai Menteri Agama pertama pada era Presiden Soekarno. Lathiful Khuluq, Fajar Kebangunan Ulama: Biografi Kiyai Hasyim Asyari (Yogyakarta: LKiS, 2000), h. 37.
} 
cara membungkukkan badan 90 derajat menghadap ke arah Tokyo setiap pagi sekitar pukul 07.00 WIB. Budaya itu wajib dilakukan penduduk tanpa kecuali, baik anak sekolah, pegawai pemerintah, kaum pekerja dan buruh, bahkan di pesantren-pesantren. Namun KH. Hasyim Asyari menentang karena dia menganggapnya haram dan dosa besar. Membungkukkan badan semacam itu menyerupai $r u k \bar{u}^{\prime}$ dalam shalat, hanya diperuntukkan menyembah Allah. Menurut KH. Hasyim Asy'ari, selain kepada Allah hukumnya haram, sekalipun terhadap Kaisar Tenno Heika yang katanya keturunan Dewa Amaterasu Dewa Langit. Akibat penolakannya itu, pada akhir April 1942, KH. Hasyim Asyari yang sudah berumur 70 tahun dijebloskan ke dalam penjara di Jombang. Kemudian dipindah ke Mojokerto, lalu ke penjara Bubutan Surabaya. Selama dalam tawanan Jepang, Kiai Hasyim disiksa hingga jari-jari kedua tangannya remuk tak lagi bisa digerakkan. ${ }^{17}$

Itulah pemikiran $\mathrm{NU}$ yang sangat gigih menentang segala bentuk penjajahan hukumnya wajib karena perintah agama, hal ini sejalan dengan garis perjuangan ulama-ulama pendahulunya yang senantiasa memberikan hukum wajib jihad untuk mengusir Belanda, sebagaimana di kutib pendapat dari ulama Palembang yaitu Syekh Abd al-Shamad al-Palimbany, ${ }^{18}$ yang mengatakan bahwa perang melawan orang kafir hukumnya fardu 'ain berlaku apabila orang-orang kafir menginvasi wilayah kaum Muslimin. Seluruh penduduk berkewajiban mempertahankan wilayahnya semaksimal mungkin. Bahkan, bila terpaksa siapapun tanpa terkecuali baik anak-anak, perempuan, faqir miskin wajib ikut jihad sesuai dengan kemampuannya masing-masing. Haram hukumnya bagi prajurit lari dari medan perang bila telah berjumpa dengan pasukan

\footnotetext{
${ }^{17}$ Saifudin Zuhri, Wejangan Hasyim Asy'ari (Jombang: Pustaka Warisan Islam, 1910), h. 29. Lihat juga: Zubair, "Jihad dan Kemerdekaan: Studi atas Naskah Nasihatul Muslimin wa Tazkiratul Mu'minin”, Jurnal: Lektur Keagamaan, Vol. 9. No.2 November 2011 Jakarta: Puslitbang Lektur Keagamaan Badan Litbang dan Diklat Kementrian Agama RI, 2011), h. 380-382.

${ }^{18} \mathrm{Al}$-Palimbany adalah 'Abd al-Shamad al-Palimbani adalah seorang ulama, ahli tasawuf sekaligus seorang mujahid dan arsitek jihad. Gelar kesufian beliau tidak diragukan lagi. Beliau termasuk salah seorang pembawa pemikiran Hujjat al-IslāmImam al-Ghazālī dan termasuk ulama yang memperkenalkan tarekat Sammaniyah di bumi Melayu-Nusantara. 'Abd al-Shamad al-Palimbani dikenal sebagai ulama tasawuf melalui dua karyanya Hidāyat al-Sālikīn dan Sìār al-Sālikīn yang keduanya merupakan terjemahan / saduran dari karya Imam al-Ghazālì Lubab Ihyā'Ulūm al-Dīn dan Bidāyah al-Hidāyah. 'Abd al-Shamad al-Palimbani berhasil menyesuaikan metafisika-tasawuf Ibn 'Arabī dengan prinsip-prinsip Imam al- Ghazālī. Menurut Azyumardi Azra, nama beliau cukup populer dan disegani di Timur Tengah. Hal ini dibuktikan dengan masuknya nama 'Abd al-Shamad al-Palimbani dalam kamus-kamus biografi Arab, Lihat Azyumardi Azra, Islam Reformis. (Jakarta: Raja Grafindo Persada,1999), h. 103.
} 
lawan. Beliau berpendapat bahwa seluruh masyarakat turut andil dalam jihad sesuai kemampuannya masing-masing, seperti memberikan akomodasi ataupun menjaga harta dan keluarga mujahiddin yang ditinggal perang. ${ }^{19}$ Sikapsikap seperti inilah yang ditunjukan oleh NU dan mayoritas ulama di Indonesia dalam memberikan fatwa jihad memerangi terhadap penjejajah Belanda.

\section{Peran Nahdlatul Ulama (NU) dalam Mewujudkan Kemerdekaan Negara Kesatuan Republik Indonesia (NKRI)}

\section{Keterlibatan Ulama NU dalam Mengusir Penjajah Belanda}

Belanda sebagai bangsa yang paling lama menguasai bangsa Indonesia sudah melakukan banyak kebijakan-kebijakan yang sangat merugikan rakyat Indonesia. ${ }^{20}$ Sikap kolonial Belanda telah menumbuhkan benih-benih ketidak puasan bangsa Indonesia sehingga para pemuka agama menghimpun kekuatan melalui dunia pesantren diantaranya adalah Nahdlatul Ulama (NU). Ditambah adanya beberapa program kristenisasi yang digalakkan oleh penjajah Belanda

\footnotetext{
${ }^{19}$ Sebagaimana penjelasan Azumardi Azra, Snouck Hurgronje menyebutkan bahwa karya Syekh alPalimbani merupakan sumber rujukan utama berbagai karya mengenai jihad dalam Perang Aceh yang sangat panjang melawan Belanda, mulai 1873 sampai awal abad ke-20. Kitab ini menjadi model imbauan agar kaum Muslim berjuang melawan kaum kafir. Lihat dalam buku: Azyumardi Azra, Jaringan Ulama Timur Tengah dan Kepulauan Nusantara Abad XVII \& XVIII Akar Pembaruan Islam Indonesia. (Jakarta, Kencana Press, 2004), h. 49. Lihat juga dalam buku: Ahmad Ibrāhim Abu Syauk, Tārïkh harakah al-Ishlāh wa al-Irsyād wa syaikh al-Irsyādiyyīn Ahmad Muhammad al-Surkatiy fi Indonesia, (Kuala Lumpur: publikasi bersama antara Research Centre International Islamic University Malaysia dan Dār al-Fajr Malaysia, 2000), h. 249-253.

${ }^{20}$ Rakyat Indonesia pastinya tidak akan pernah lupa sejarah penjajajahan Belanda di Indonesia, Belanda menjajah Indonesia selama tiga setengah abad (bahkan jika dihitung sejak zaman Portugis, penjajahan di Indonesia justeru berlangsung selama 434 tahun, yakni sejak 1511-1945. Belum lagi agresi militer Belanda II yang berakhir pada tahun 1949). Pada tahun 1856 merupakan awal kedatangan Bangsa Belanda ke Negara Indonesia. Empat buah kapal yang dipimpin oleh Pieter Keyzer serta Cornelis de Houtman ini sampai ke pelabuhan Banten setelah menempuh perjalanan selama satu tahun lebih. Sayangnya, kunjungan dari kapal Belanda ini ke daerah Banten kurang disambut baik karena sifat arogan yang ditunjukkan oleh Cornelis de Houtman. Kemudian dua tahun kemudian, tepatnya pada tahun 1858 Belanda mencoba lagi kembali ke Indonesia di bawah pimpinan Jacob Van Neck, dan mereka berhasil disambut baik oleh penguasa Banten saat itu karena mereka telah belajar dari kesalahan Cornelis de Houtman. Akhirnya, Belanda diperbolehkan untuk melakukan perdagangan di kawasan pelabuhan Banten. Tujuan awal Belanda adalah untuk berdagang rempah-rempah, namun setelah mereka berhasil mendapatkan keuntungan melimpah serta menemukan daerah sumber rempah-rempah, Belanda mulai melakukan aksi monopoli perdagangan dan sejarah penjajahan Belanda di Indonesia pun dimulai, berawal dari sinilah lalu Belanda mengembangkan penjajahanya di Nusantara selama tiga abad lebih. Lihat, Thomas Stamford Raffles, The History of Java Uakarta: Narasi Press 1976), h. 78. Dan Lihat: Syaifuddin Zuhri, Sejarah Kebangkitan Islam dan Perkembangannya di Indonesia (Bandung: Al-Ma'arif, 1979), h. 29.
} 
di bumi nusantara ini menjadikan Nahdlatul Ulama bangkit menghimpun laskar-laskar kekuatan (hizbulläh) untuk melawan penjahan Belanda yang dianggap kafir dan dhalim. NU dengan segala kekuatan yang ada pada tingkat komunitas masyarakatnya secara menyeluruh memberikan pengaruh yang mengakibatkan munculnya kelompok baru yang disebut ulama dan santri, yang kemudian karena kekuatan NU ini semakin lama semakin kuat, maka oleh penjajah Belanda ingin dijauhkan dari pengaruh politiknya. ${ }^{21}$

Menurut Alamsyah Ratu Perwiranegara, pandangan dan cara hidup Islam yang memunculkan ulama dengan pesantrennya, dinyatakan tidak hanya dengan mengadakan perubahan sosial saja, tetapi lebih cenderung menumbuhkan revolusi sosial sebagai perubahan yang radikal dan meluas yang berdasar pada perubahan sikap mental. ${ }^{22}$ Arus perubahan seperti ini pada gilirannya mendapatkan tantangan baru, yakni adanya agresi perdagangan dan agama yang dilancarkan oleh imperialis Barat. Menjawab tantangan ini, para ulama bekerja keras untuk membina santri-santrinya agar memiliki sikap combative spirit (semangat siap tempur). Pesantren yang tadinya merupakan lembaga pendidikan, bertambah fungsinya sebagai tempat kegiatan membina pasukan sukarela yang akan disumbangkan untuk mempertahankan agama, bangsa dan Negara Kesatuan Republik Indonesia. ${ }^{23}$

Menurut Thomas Stamford Raffles, peran kelompok ulama yang strategis ini bukanlah hasil dari voting (pemilihan suara) atau dari pengaruh karisma raja, tetapi lahir dari perkembangan Islam itu sendiri yang memandang ulama

21Lihat: Nurlira Goncing, "Politik Nahdlatul Ulama dan Orde Baru”, The Politics: Jurnal Magister Ilmu Politik UNHAS, Vol. 1, N.1, 2015, h.67-68. Lihat juga: Ahmad Mansur Suryanegara, Menemukan Sejarah: Wacana Pergerakan Islam di Indonesia (Bandung: Mizan, 1996) h. 235.

${ }^{22}$ Gerakan sosial yang dipimpin oleh para ulama pernah berbelok menjadi gerakan Ratu Adil. Hal ini disebabkan karena runtuhnya wibawa raja-raja atau pemerintahan pribumi yang didukungnya, sehingga umat Islam merasa tidak lagi memiliki pemerintahan yang patut dipatuhi. Kalangan petani miskin yang hidup dalam alam feodal merupakan kelompok masyarakat tertindas. Satu-satunya pemimpin yang dianggap mampu dan masih memihak kepada kepentingannya adalah ulama. Lihat: Alamsjah Ratu Perwiranegara, Islam dan Pembangunan Politikdi Indonesia (Jakarta: CV Haji Masagung, 1987) h. 186.

${ }^{23}$ Pesantren tidak hanya merupakan lembaga pendidikan, tetapi juga merupakan lembaga penyemaian kader-kader pemimpin rakyat, sekaligus berfungsi sebagai wahana merekrut prajurit sukarela yang memiliki keberanian moral yang tinggi. Di hatinya telah ditanamkan ajaran jihad untuk membela agama, Negara dan bangsa dengan harta, ilmu, dan jiwanya. Keyakinan ajaran yang dijiwai Islam ini merupakan faktor psikologis yang sangat penting dalam menghadapi apapun. Lihat: Abdul Ghoffir Muhammad, "Pesantren and Tarekat in the Modern Era: An Account of the Transmission of Traditional Islam in Java", Jurnal Studia Islamika, Vol. 4, No. 1, 1997, h. 17-25. Lihat juga: Bernard H.M. Vlekke, Nusantara Sejarah Indonesia (Jakarta: Kepustakaan Populer Gramedia, 2010), h. 391. 
sebagai kelompok intelektual Islam, dan tampaknya telah menjadi watak dasar bangsa Indonesia yang selalu mengangkat kalangan berilmu sebagai pemimpinnya. Kehadiran ulama dalam masyarakat telah diterima sebagai pelopor pembaharuan, dan pengaruh ulama pun semakin mendalam setelah berhasil membina pesantren. Eksistensi ulama jangan dilihat hanya sekedar sebagai pembina pesantren saja, akan tetapi peranannya dalam sejarah perjuangan bangsa cukup militan. Sekalipun banyak penulis sejarah yang menyingkirkan peran para ulama dalam karyanya, namun Raffles menuliskan betapa besar peranan ulama dalam menunjang para Sultan melawan Belanda. Menurutnya, "ulama merupakan kelompok intelektual yang sangat kuat dan membahayakan di tangan penguasa-penguasa pribumi dalam rangka melawan penjajahan Belanda dan kelompok ulama senantiasa aktif menggerakkan perjuangan dan memberikan spirit untuk melakukan pemberontakan pada penjajah Belanda". ${ }^{24}$ Kelanjutan dari pengaruh ulama yang demikian luas tersebut tidak hanya terbatas di bidang politik dan militer saja, melainkan meluas juga terhadap ekonomi yang telah meninggalkan bekas-bekasnya baik berupa aktivitas perdagangan, tukar menukar barang ekonomi, kegiatan perniagaan lain yang produktivitasnya untuk menopang perekonomian keluarga dan perjuangan agama. Pasar tidak hanya merupakan kegiatan jual beli barang dagangan, tetapi juga dijadikan arena dakwah, sehingga kegiatan pasar sangat dipengaruhi oleh hari-hari besar Islam. Jadi, Islam sebagai agama yang disebarkan di Indonesia oleh para ulama, memiliki peran yang positif dalam menunjang kegiatan-kegiatan sosial, politik dan kegiatan perekonomian dan perdagangan. $^{25}$

Kalau kita perhatikan data di atas, jelaslah bahwa kepentingan Belanda di Indonesia mendapatkan rintangan dari ulama, terutama di bidang perdagangan

\footnotetext{
${ }^{24}$ Thomas Stamford Raffles menyatakan: "and they become the most dangerous instrument in the hands of the native authorities opposed to the Dutch interest" ....... The Mahometan priests have almosth invariably been found most active in every case of insurrection. Lihat: Thomas Stamford Raffles, The History ofJava (Jakarta: Narasi Press, 1976), h. 77.

25Ditinjau dari angka penerbitan buku Raffles di atas (1817), seperti memberikan kesan bahwa jumlah ulama saat itu sangat banyak. Tetapi nyatanya jumlah ulama kurang lebih 50.000 (lima puluh ribu), yang merupakan sepersembilan belas dari seluruh jumlah penduduk. Dengan demikian, tidaklah berlebihan kalau dikatakan bahwa ulama mempunyai peranan penting dalam pembangunan militer. Kapasitas pasukan santrinya telah mensuplai kepentingan politik, perdagangan dan agama. Serta akibat lain dari peranan yang didudukinya, menjadikan Al Quran dan Sunnah sebagai sumber norma dalam memerintah seluruh kegiatan rakyat. Lihat: Thomas Stamford Raffles, The History of Java (Jakarta: Narasi Press, 1976), h. 76.
} 
dan kebijakan politik kolonial. Belanda melihat kegiatan umat Islam yang mempunyai dwi fungsi sebagai pedlar missionaries (da'i dan pedagang), mengakibatkan usaha perdagangan Belanda menghadapi ancaman dari umat Islam, maka tidaklah mengherankan kalau Islam dijadikan sebagai senjata politik dalam melawan Calvinisme VOC Belanda. ${ }^{26}$ Para ulama dan para kiai mempunyai pengaruh yang sangat besar, terlebih karena sifat pendidikan agama di pesantren, pondok yang mengarah pada orientasi vertikal kalangan santri kepada para gurunya -yang dalam filosofis diartikan harus di"gugu” dan di"tiru" - menyebabkan pengaruh kewibawaan para ulama dan kiai sangat besar. Karena itulah, dalam menjangkau perspektif pembangunan politik di Indonesia dalam arti yang seluas-luasnya, para ulama sangat berperan penting dalam kehidupan bermasyarakat, berbangsa dan bernegara. ${ }^{27}$

Peran ulama dalam perjuangan kemerdekaan negara Republik Indonesia tidak hanya sebagai pengobar semangat santri dan masyarakatnya, akan tetapi juga bertujuan "mempengaruhi" pemerintah agar segera menentukan sikap melawan kekuatan asing yang ingin menggagalkan kemerdekaan negara Republik Indonesia.28 Jauh sebelumnya, yaitu masa pendudukan Jepang, kaum

\footnotetext{
26Setelah berkuasa cukup lama di Nusantara, dalam perkembangan selanjutnya VOC mengalami kemunduran. Hal itu disebabkan oleh berbagai faktor, di antaranya: 1) merebaknya tindakan korupsi di kalangan para pegawai VOC; 2) adanya persaingan dagang yang ketat di antara sesama kongsi dagang negara lain seperti Compagnie des Indies (CDI) dari Prancis, dan East Indian Company (EIC) dari Inggris; 3) membengkaknya biaya perang yang dikeluarkan oleh VOC untuk mengatasi pemberontakan yang dilakukan rakyat Indonesia di daerah-daerah; 4) akibat kekuasaan VOC yang cukup luas menyebabkan kebutuhan gaji pegawai semakin membengkak yang menyebabkan kebangkrutan. Akibat dari kemunduran yang dialami VOC, akhirnya pada tahun 1795 dibentuklah panitia pembubaran VOC, maka secara resmi pada tanggal 31 Desember 1799 VOC sudah bubar. Berakhirnya kekuasaan VOC di Indonesia pada 31 Desember 1799 menyebabkan kekuasaan Belanda semakin memudar. Pada tahun 1602 didirikanlah kongsi dagang Belanda yang diberi nama Vereenigde Oost-Indische Compagnie (VOC). Adapun tujuan Belanda mendirikan VOC adalah: 1) menghindarkan persaingan antar pengusaha Belanda, 2) mendapatkan keuntungan yang sebesar-besarnya. 3) agar mampu bersaing dengan kongsi dagang dari bangsa lain, seperti Portugis dan Spanyol. Lihat: Jajat Burhanuddin, Ulama dan Kekuasaan: Pergumulan Elite Muslim dalam Sejarah Indonesia (Jakarta: Mizan, 2012), h. 86.

${ }^{27}$ Data sejarah di atas memberikan ilustrasi kepada kita tentang betapa besarnya peranan ulama dalam setiap perlawanan bersenjata. Tidak hanya terlihat sekedar sebagai pembina pesantren, tetapi telah diakui oleh Thomas Stamford Raffles bahwa ulama merupakan partnership para pengusaha dalam melawan usaha perluasan kekuasaan asing di Indonesia. Dengan demikian, ulama memegang peranan multifungsi, termasuk bidang politik dan militer. Lihat dalam buku: Ahmad Mansur Suryanegara, Menemukan Sejarah: Wacana Pergerakan Islam di Indonesia (Bandung: Mizan, 1996) h. 238.

${ }^{28}$ Semangat Jihad juga tersebar melalui berbagai persaudaraan sufi. Sederet pemberontakan melawan penajajah pada akhir abad ke-19 banyak dilakukan. Tarekat Sammaniyah terlibat dalam pemberontakan anti-Belanda di Palembang (1819) dan Kalimantan Selatan (1860-an); Tarekat Qadiriyah wa Naqsyabandiyah (yang didirikan oleh Syeikh Ahmad Khatib Sambas) terlibat dalam pemberontak-
} 
ulama dan santrinya sudah bersiap-siap menyusun kekuatan. Laskar Hizbullāh (Tentara Allah) dan Sabilillāh (Jalan Allah) didirikan menjelang akhir pemerintahan Jepang, dan mendapat latihan kemiliteran di Cibarusah, sebuah desa di Kabupaten Bekasi, Jawa Barat. Laskar Hizbullāh berada di bawah komando spiritual KH. Hasyim Asy'ari dan secara militer dipimpin oleh KH. Zaenul Arifin. Adapun laskar Sabïlillāh dipimpin oleh KH. Masykur, dia adalah pemuda pesantren dan anggota Ansor NU (ANU) sebagai pemasok paling besar dalam keanggotaan Hizbullāh.29 Peran kiai dan santri dalam perang kemerdekaan ternyata tidak hanya dalam laskar Hizbullāh dan Sabīlillāh saja, tetapi banyak diantara mereka yang menjadi anggota tentara PETA (Pembela Tanah Air). ${ }^{30}$

Menurut Martin van Bruinessen, lahirnya "Resolusi Jihad" tidak terlepas dari peran Hizbullāh, peran mereka nyata terlihat setelah berkumpulnya para kiai se-Jawa dan Madura di kantor ANO (Ansor Nahdlatul Oelama) pada tanggal 21 Oktober 1945. Setelah rapat darurat sehari semalam, maka pada 22 Oktober dideklarasikan seruan jihad fi sabïlillāh yang belakangan dikenal dengan istilah "Resolusi Jihad", 31 ketika NU melihat ancaman terhadap negara yang sudah

an Banten (1888), Sidoarjo (1903) dan Lombok (1891-1894); Tarekat Syatariyah terlibat dalam pemberontakan anti-pajak di Tanah Minagkabau (1908) (Loir, 2013: 37-38). Lihat dalam buku: Ahmad Dahlan, Sejarah Melayu. (Jakarta, Gramedia, 2014), h. 27. Lihat juga: Braginksy, Yang Indah, Berfaedah dan Kamal: Sejarah Sastra Melayu dalam Abad 7-19. (Jakarta: V. I. INIS Press, 1998), h. 121.

${ }^{29}$ Nama hizbullāh diambil dari kata Arab yang berarti tentara Allah, oleh karena itu dengan terbentuknya Hizbullāh diharapkan sebagai wadah umat Islam untuk menopang cita-cita dalam meraih kemerdekaannya. Keberadaan Hizbullāh juga diharapkan akan membawa angin segar bagi Jepang untuk membantu pertahanan dalam menghadapi sekutu. Setelah tentara Hizbullāh terbentuk, para tokoh Islam segera mengkampanyekan kepada seluruh ummat Islam di Jawa, Sumatera, Kalimantan, Sulawesi dan daerah-daerah lain di Indonesia untuk mengkumpulkan para pemuda Islam yang akan dididik dalam kemiliteran tokoh-tokoh Islam tidak menemui kesulitan, sebab para pemuda Islam telah memiliki kesadaran yang cukup tinggi dalam membela tanah airnya dari cengkraman penjajah Belanda, dan Menurut penelitian Agus Sunyoto, dari enam puluh bataliyon tentara PETA, hampir separuh komandannya adalah para kiai. Lihat: M. Mas'ud Adnan, Resolusi Jihad dalam Peristiwa 10 November, h. 87. Lihat juga dalam: NU Online, KH. Zainul Arifin, panglima Hizbullah, Seorang Pahlawan, November 2015.

${ }^{30}$ Laffan, Michael Francis, Islamic Nationhood and Colonial Indonesia; The Umma below the Winds, London: Routledge Curzon, 2003, h.74. lihat juga: Bizawie, Laskar Ulama dan santrinya \& Resolusi Jihad; Garda Depan Menegakkan Indonesia 1945-1949 h. 29.

31Sejarawan Belanda Bruinessen mengakui bahwa "Resolusi Jihad" ini tidak mendapat perhatian yang layak dari para sejarawan, patut diketahui, bahwa munculnya Resolusi Jihad berkat peran penting dari laskar hizbullāh dan sabïlillāh dimana laskar rakyat ini paling kuat yang pernah hidup di bumi Indonesia Meskipun dalam sejarah, keberadaan laskar tersebut disisihkan. Buktinya, perjuangan mereka tidak ditemukan dalam museum-museum. Boleh jadi, para laskar ini seringkali berselisih paham dengan pemerintah Soekarno yang tidak bersikap tegas dalam menentang pendaratan pasukan 
menyatakan proklamasi kemerdekaannya, dan sudah mempunyai konstitusinya sendiri (UUD 1945), maka pada tanggal 22 Oktober 1945, organisasi ini mengeluarkan sebuah "Resolusi Jihad". Sedangkan tokoh ulama NU yang memprakarsai "Resolusi Jihad” ini adalah KH. Hasyim Asy'ari (1875-1947 M), KH. Wahab Hasbullah (1888-1971 M), Kiai Bisri Syansuri (1886-1980 M) dan Kiai Abbad Buntet (1879-1946 M). ${ }^{32}$ Ketika NU melihat ancaman terhadap negara yang sudah menyatakan proklamasi kemerdekaannya, dan sudah mempunyai konstitusinya sendiri (UUD 1945), maka pada tanggal 22 Oktober 1945, organisasi ini mengeluarkan sebuah "Resolusi Jihad". Namun, sebelumnya NU mengirim surat resmi kepada pemerintah yang berbunyi: "Memohon dengan sangat kepada pemerintah Indonesia supaya menentukan sikap dan tindakan yang nyata serta sepadan terhadap tiap-tiap usaha yang akan membahayakan kemerdekaan agama dan negara Indonesia, terutama terhadap Belanda dan kaki tangannya. Supaya pemerintah melanjutkan perjuangan yang bersifat $f i$ sabīlillāh untuk tegaknya Negara Republik Indonesia yang merdeka dan beragama Islam." 33

Adapun resolusi yang diputuskan dalam rapat para konsul NU se-Jawa itu berbunyi:

1) Kemerdekaan Indonesia yang diproklamirkan pada 17 Agustus 1945 wajib dipertahankan.

2) Republik Indonesia (RI) sebagai satu-satunya pemerintahan yang sah, wajib dibela dan diselamatkan.

3) Musuh negara Republik Indonesia, terutama Belanda yang datang dengan membonceng tentara Sekutu (Inggris) dalam masalah tawanan

Sekutu dan Belanda ketika itu. Lihat; Martin van Bruinessen dalam NU: Tradisi, Relasi-relasi Kuasa, Pencarian Wacana Baru (baca: KH. Hasyim Asy'ari: Menjaga Tradisi Pesantren), 1997, h. 76.

${ }^{32}$ Sebagaimana yang diceritakan oleh Kiai Abbas Buntet Cirebon, bahwa pada tanggal 21-22 Oktober 1945 Kiai Abbas ikut andil dalam keputusan Resolusi Jihad, yang merupakan keputusan para kiai dalam rapat Nahdlatul Ulama di Bubutan Surabaya, beberapa kiai, di antaranya Hadratus Syaikh Hasyim Asy'ari, Kiai Wahab Chasbullah, Kiai Bisri Syansuri, Kiai Abbas Buntet, Kiai Wahid Hasyim, dan beberapa kiai lainnya berkumpul dalam sebuah majelis untuk membahas penyerbuan tentara NICA (Netherlands Indies Civil Administration). Fatwa Jihad yang digelorakan Hadratus Syaikh Hasyim Asy'ari akhirnya menjadi catatan sejarah, sebagi pengobar semangat kaum santri untuk berjuang mempertahankan negeri. Lihat: Abdul Wahid, Peranan Pondok Pesantren Buntet Cirebon bagi Kemajuan Lingkungan Pendidikan di Lingkungan Sekitar 1958-2009 (Semarang: Universitas Negeri Semarang Press, 2012), h. 72. Lihat juga: Abdul Ghoffir Muhaimin, The Islamic Tradition of Cirebon: Ibadat and Adat among Javanese Muslim (Canberra: ANU Press, 2006), h. 71.

33Lihat: Akira Nagazumi, Bangkitnya Nasionalisme Indonesia Budi Utomo 1908-1918 Jakarta: Pustaka Utama Grafiti, 1989), h. 99. 
perang bangsa Jepang tentulah akan menggunakan kesempatan politik dan militer untuk kembali menjajah Indonesia.

4) Umat Islam, terutama NU wajib mengangkat senjata melawan Belanda dan kawan-kawannya yang hendak kembali menjajah Indonesia.

5) Kewajiban tersebut adalah jihad yang menjadi kewajiban tiap-tiap Muslim yang berada pada jarak radius $94 \mathrm{~km}$ (jarak dimana umat Islam diperkenankan shalat jamā' dan qașr). ${ }^{34}$

Resolusi jihad tersebut akhirnya mampu membangkitkan semangat arekarek Surabaya untuk bertempur habis-habisan melawan penjajah. Dengan semangat takbir yang dipekikkan oleh Bung Tomo, maka terjadilah perang rakyat yang heroik pada 10 November 1945 di Surabaya. Dari sejarah ini, warga NU dan para elitnya, tidak menjadi alergi ketika akhir-akhir ini ada upaya untuk mengebiri dan mengaburkan makna jihad. Resolusi Jihad yang diserukan KH. Hasyim Asy'ari, sebaiknya diingat kembali untuk memberikan motivasi kepada generasi muda dalam mempertahankan kemerdekaan dan kedaulatan bangsa dan negara. ${ }^{35}$

\section{Keterlibatan NU sebagai Panitia Persiapan Kemerdekaan RI}

Keterlibatan Nahdlatul Ulama (NU) mempunyai arti penting dalam perumusan Pembukaan Undang-Undang Dasar negara Republik Indonesia, yang terbentuk dalam Panitia Sembilan dalam BPUPKI (Badan Penyelidik UsahaUsaha Persiapan Kemerdekaan Indonesia) tahun 1945 yang menghasilkan dokumen sejarah penting, yaitu "Piagam Jakarta" ${ }^{36}$. Syukurlah rumusan "Atas berkat

\footnotetext{
${ }^{34}$ M. Mas'ud Adnan, Resolusi Jihad dalam Peristiwa 10 November, h. 87. Lihat juga dalam: Lathiful Khuluq, Fajar Kebangunan Ulama: Biografi Kiyai Hasyim Asyari, (Yogyakarta: LkiS, 2000), h. 29

${ }^{35}$ Tak dipungkiri, semangat ke-jam'iyyah-an NU di kalangan generasi muda kini semakin merosot. Pada lingkup internal, banyak kader-kader muda NU yang tidak mengerti rangkaian sejarah Resolusi Jihad. Survei membuktikan, ingatan masyarakat tentang Resolusi Jihad NU 1945 yang memiliki mata rantai dengan Peristiwa 10 November di Surabaya semakin punah. "Oleh karena itu, wacana Resolusi Jihad NU harus dihidupkan kembali, direkonstruksi dan tidak ditempatkan pada upaya politisasi sejarah. Tanpa Resolusi Jihad, tidak akan ada NKRI seperti yang kita cintai saat ini," kata Gugun ElGuyanie, penulis buku Resolusi Jihad Paling Syar'i. Jangankan masyarakat umum, generasi-generasi penerus NU dari pusat sampai ranting, Ansor-Fatayat, IPNU-IPPNU pun banyak yang tidak mendapatkan transfer seiarah mengenai resolusi penting itu. Lihat: M. Mas'ud Adnan, Resolusi Jihad dalam Peristiwa 10 November, h. 101.

36"Piagam Jakarta" adalah naskah Pembukaan (Preambule) Undang-undang Dasar (UUD) 1945 yang disiapkan untuk konstitusi Negara Indonesia merdeka. Ketika naskah pembukaan itu sudah disepakati, maka naskah-naskah rincian pasal-pasal dalam UUD 1945 masih menjadi masalah yang diperdebatkan. Dalam sidang BPUPKI tanggal 13 Juli 1945, KH Wahid Hasyim mengusulkan, agar Presiden adalah orang Indonesia asli dan "yang beragama Islam". Begitu juga draft pasal 29 diubah
} 
rahmat Allah... " itu tidak dituntut untuk dicoret sebagaimana rumusan tujuh kata "(Ketuhanan)... dengan kewajiban menjalankan syariat Islam bagi pemeluk-pemeluknya....", seperti kita pahami "tujuh kata" itu kemudian dicoret dalam sidang PPKI (Panitia Persiapan Kemerdekaan Indonesia) tanggal 18 Agustus 1945. Bung Hatta mengaku, ia mendapat telepon dari seorang perwira Jepang yang mengaku menyampaikan aspirasi kaum Kristen Indonesia Timur, bahwa mereka tidak mau bergabung dengan NKRI jika "tujuh kata" itu tidak dihapus ${ }^{37}$. Hingga kini, peristiwa seputar pencoretan "tujuh kata" itu masih misterius, sebab sampai meninggalnya Bung Hatta tidak membuka siapa sebenarnya perwira Jepang yang meneleponnya tersebut. ${ }^{38}$

Menurut KH. Wahid Hasyim, bahwa toleransi yang dilakukan oleh NU dan tokoh-tokoh pejuang Muslim lain yang menerima untuk menghapus "tujuh kata" dan menerima tuntutan kaum Kristen Indonesia Timur, itu semua merupakan pengorbanan dan perjuangan para ulama $\mathrm{NU}$ demi terpeliharanya kemerdekaan dan juga demi persatuan dan kesatuan NKRI. ${ }^{39}$ Kita perlu meng-

dengan ungkapan: "Agama Negara ialah agama Islam", dengan menjamin kemerdekaan orang-orang yang beragama lain, untuk dan sebagainya..... Menurut KH. Wahid Hasyim: "Hal ini erat perhubungan dengan pembelaan, pada umumnya pembelaan yang berdasarkan atas kepercayaan sangat hebat, karena menurut ajaran agama, nyawa hanya boleh diserahkan buat ideologi agama." Lihat: Zainul Milal Bizawie, Laskar Ulama dan Santrinya \& Resolusi Jihad..., h. 208.

${ }^{37}$ Bung Hatta berkata: "Pada sore harinya saya menerima telepon dari Nisyijima, pembantu Admiral Maeda menanyakan, dapatkah saya menerima seorang opsir Kaigun (Angkatan Laut), karena ia mau mengemukakan suatu hal yang sangat penting bagi indonesia. Nisyijima sendiri yang akan menjadi juru bahasanya. Saya persilahkan mereka datang. Opsir itu yang saya lupa namanya, datang sebagai utusan Kaigun untuk memberitahukan dengan sungguh-sungguh, bahwa wakil-wakil Protestan dan Katolik dalam daerah-daerah yang dikuasai oleh Angkatan Laut Jepang, berkeberatan sangat terhadap bagian kalimat dalam pembukaan Undang-Undang Dasar, yang berbunyi, "Ketuhanan dengan kewajiban menjalankan syari'at Islam bagi pemeluk-pemeluknya". Mereka mengakui bahwa bagian kalimat itu tidak mengikat mereka, hanya mengenai rakyat yang beragama Islam. Tetapi tercantumnya ketetapan seperti itu di dalam suatu dasar yang menjadi pokok Undang-Undang Dasar berarti mengadakan diskriminasi terhadap golongan minoritas. Jika "diskriminasi” itu ditetapkan juga, mereka lebih suka berdiri di luar Republik Indonesia." Lihat dalam buku beliau yang berjudul "Sekitar Proklamasi 17 Agustus 1945”, pada bab 5 "Pembentukan indonesia Merdeka oleh Panitia Persiapan Kemerdekaan Indonesia", halaman 66-67, Bung Hatta menjelaskan seputar perubahan rangkaian kata tersebut. Lihat: Mohammad Hatta, Sekitar Proklamasi 17 Agustus 1945, (Jakarta: Tintamas Press, 1969), h. 66-67.

${ }^{38}$ Nurlira Goncing, "Politik Nahdlatul Ulama dan Orde Baru”, The Politics: Jurnal Magister Ilmu Politik UNHAS,Volume 1, Number1,2015,h.68.

${ }^{39}$ Contoh pengorbanan yang dilakukan oleh ulama Indonesia adalah KH. Wahid Hasyim, beliau Usul KH. Wahid Hasyim disokong oleh Soekiman. Tapi, Haji Agus Salim mengingatkan, bahwa usul itu berarti mementahkan kembali kesepakatan yang telah dibuat sebelumnya antara golongan Islam dan golongan kebangsaan. Usulan Wahid Hasyim akhirnya ditolak. Tapi, pada sidang tanggal 14 Juli 1945, Ki Bagus Hadikoesoemo, tokoh Muhammadiyah kembali mengangkat usul Kiai Sanusi yang meminta agar 
ingat kembali, bahwa setelah "Piagam Jakarta" ditetapkan, masih ada sebagian anggota BPUPKI yang menggugatnya. Akhirnya, Bung Karno sendiri menegaskan: "Saya ulangi lagi bahwa ini satu kompromis untuk menyudahi kesulitan antara kita bersama. Kompromis itu pun terdapat sesudah keringat kita menetes. Tuan-tuan, saya kira sudah jelas bahwa kalimat "dengan didasarkan kepada ke-Tuhanan dengan kewajiban menjalankan syariat Islam bagi pemeluk-pemeluknya...." sudah diterima oleh Panitia ini".40 Inilah debat panjang yang akhirnya menelorkan sikap kompromis yang sebaik-baiknya antara kaum muslimin dan kristen. Sehingga panitia memegang teguh akan kompromis yang dinamakan oleh anggota yang terhormat Muh. Yamin dengan nama "Djakarta Charter", yang disertai perkataan Tuan anggota Soekiman, gentlemen agreement, hal ini supaya dipegang teguh di antara pihak Islam dan pihak kebangsaan." 41

Piagam Jakarta adalah cikal bakal materi Pembukaan UUD 1945 oleh karena materi Piagam Jakarta kemudian dijadikan materi pembukaan (preambule) UUD 1945. Piagam Jakarta berisi pula kalimat proklamasi kemerdekaan Indonesia yang dinyatakan pada 17 Agustus 1945. Persiapan yang dilakukan oleh para tokoh bangsa termasuk salah satu perumus Pancasila yaitu KH. Abdul Wahid Hasyim dari kalangan tokoh agama, ${ }^{42}$ beliau melakukan langkah dengan menggelar rapat di Taman Raden Saleh Jakarta pada tanggal 13-14 September 1944. Sebulan kemudian, Masyumi mengadakan rapat khusus dengan kesepakatan untuk mengajukan resolusi kepada Jepang agar segera mempersiapkan umat Islam Indonesia untuk siap menerima kemerdekaan. Di saat tentara Negara belum efektif terutama jalur komandonya, Laskar ulama dan santrinya telah sigap menghadapi berbagai ancaman yang akan terjadi. Bahkan konsolidasi dan jalur komando laskar Hizbullāh dengan dukungan struktur Nahdlatul Ulama (NU) dan Masyumi begitu massif hingga

frase "bagi pemeluk-pemeluknya" dalam Piagam Jakarta dihapuskan saja. Jadi, bunyinya menjadi: "Ketuhanan, dengan kewajiban menjalankan syariat Islam." Lihat: Zainul Milal Bizawie, Laskar Ulama dan Santrinya \& Resolusi Jihad ..., h. 21.

40Mohammad Hatta, Sekitar Proklamasi 17 Agustus 1945, (Jakarta: Tintamas Press, 1969), h. 19. Lihat juga dalam: Panji Islam, No. 29,22 Juni 1940, sebagaimana dikutip oleh Deliar Noer, Gerakan Moderen Islam di Indonesia (Jakarta LP3ES, 1980), h. 308.

41A.B. Kusuma, Lahirnya Undang-Undang Dasar 1945 Jakarta: Badan Penerbit Fakultas Hukum Uiversitas Indonesia, 2004), h. 85.

${ }^{42} \mathrm{Hal}$ ini diungkapkan oleh KH Abdurrahman Wahid atau Gus Dur dalam salah satu kolomnya berjudul “Kemerdekaan: Suatu Refleks”, Majalah Aula, 1991, h. 41. 
ke pedesaan. Sebagai bentuk dukungan, laskar tetap loyal terhadap negara, ini ditandai dengan meleburnya laskar Hizbullāh dan Sabïlillāh NU ke dalam TNI dan terus aktif terlibat dalam berbagai serangan umum terhadap markas Belanda. Kegigihan para pejuang TNI dan laskar Hizbullāh, Sabīlillāh NU menunjukkan kepada dunia bahwa bangsa Indonesia tetap eksis meskipun ibukota sudah diluluhlantahkan oleh kolonial Belanda. ${ }^{43}$ Perjuangan ini akhirnya membuahkan hasil dengan diakuinya kedaulatan negara Republik Indonesia dalam perundingan Konferensi Meja Bundar (KMB), ${ }^{44}$ yang hasil keputusannya adalah Kerajaan Belanda menyerahkan kedaulatan negara Indonesia dan kemerdekaanya secara penuh dengan tidak bersyarat dan tidak dicabut lagi.

\section{Kontribusi Nahdlatul Ulama (NU) dalam Mempertahankan Kedaulatan Negara Kesatuan Republik Indonesia (NKRI)}

Di tengah era globalisasi yang melahirkan ideologi kapitalisme, kedaulatan wilayah KRI menghadapi tantangan dari upaya-upaya pencaplokan pulaupulau terpencil oleh karena itu negara dituntut ekstra sensitif untuk menjamin keamanan negaranya dari ancaman kedaulatan bangsanya. Dengan segala dampak yang menguntungkan dan merugikan dari globalisasi, negara diwajib-

\footnotetext{
${ }^{43} \mathrm{KH}$. Wahid Hasyim merupakan pendiri tentara Hizbullāh, yang dibentuk dengan dengan beberapa ulama yang ada dalam Masyumi yang bertujuan untuk mendidik para santri dalam bidang kemiliteran dan untuk mempersiapkan perang melawan penjajah Belanda untuk merebut kemerdekaan. R. Moh. Kafrawi, dkk, Sejarah Hidup KH. A. Wahid Hasyim dan Karangan Tersiar (Bandung: Al-Ma'arif, 1958), h. 307-319.

${ }^{44}$ Konferensi Meja Bundar adalah sebuah pertemuan yang dilaksanakan di Den Haag Belanda, dari 23 Agustus sampai 2 Nopember 1949 antara perwakilan Republik Indonesia, Belanda dan BFO (Bijeenkomst voor Federal Overleg) yang mewakili berbagai negara yang diciptakan Belanda di kepulauan Indonesia. KMB ini dilatarbelakangi oleh usaha untuk meredam kemerdekaan Indonesis dengan jalan kekerasan berakhir dengan kegagalan. Belanda mendapat kecaman keras dari dunia internasional. Belanda dan Indonesia kemudian mengadakan beberapa pertemuan untuk menyelesaikan masalah ini secara diplomasi, lewat perundingan Linggajati dan perjanjian Renville. Pada 28 Januari 1949, Dewan keamanan PBB meloloskan resolusi yang mengecam atas serangan militer Belanda terhadap tentara Republik Indonesia dan menuntut dipulihkannya pemerintah Republik Indonesia, diserukan pula kelanjutan perundingan untuk menemukan penyelesaian damai antara dua pihak. Untuk menuju kemerdekaan ini maka dibentuklah Konferensi Meja Bundar yang menghasilkan keputusan sebagai berikut: (1) Keradjaan Nederland menjerahkan kedaulatan atas Indonesia jang sepenuhnja kepada Republik Indonesia Serikat dengan tidak bersjarat lagi dan tidak dapat ditjabut, dan karena itu mengakui Republik Indonesia Serikat sebagai Negara jang merdeka dan berdaulat. (2) Republik Indonesia Serikat menerima kedaulatan itu atas dasar ketentuan-ketentuan pada Konstitusinja; rantjangan konstitusi telah dipermaklumkan kepada Keradjaan Nederland. Lihat: Zuhdi Mukhdlor, NU dan Politik, (Yogyakarta: PT. Gunung Jati dan Pondok Pesantren al-Munawwir Krapyak, 1986), h. 21. Lihat juga: Suryanegara, Ahmad Mansur, Api Sejarah: Mahakarya Perjuangan Ulama dan Santri..., h. 54.
} 
kan untuk lebih memperhatikan keamanan dari perspektif non-konvensional. Dimana aspek-aspek ideologi, ekonomi, budaya, sosial-politik, teknologi, militer, dan pertahanan negara sebagai dimensi yang bisa terancam sewaktu-waktu oleh siapapun dan negara manapun. Ancaman yang harus kita tanggulangi dalam rangka mempertahankan keutuhan NKRI (Negara Kesatuan Republik Indonesia) adalah setiap upaya dan kegiatan, baik dari dalam negeri maupun luar negeri yang dinilai mengancam atau membahayakan kedaulatan negara, keutuhan wilayah negara, dan keselamatan segenap bangsa harus segera ditangani secara serius, dikarenakan wilayah Indonesia baik darat maupun perairan memiliki kekayaan alam yang melimpah sehingga menjadi sasaran negara lain untuk memiliki dan menguasainya.

Bahaya pencaplokan pulau-pulau terpencil yang dilakukan oleh negara lain, dalam perspektif Nahdlatul Ulama (NU), bahwa hubungan antara bangsa baik di bidang politik, ekonomi dan kebudayaan harus dilakukan berdasarkan atas prinsip-prinsip kesetaraan dan keadilan serta membuang segala bentuk eksploitasi dan penjajahan. Karena itu segala bentuk investasi dan bantuan asing haruslah diletakkan sebagai upaya emansipasi rakyat bukan sebaliknya untuk menciptakan ketergantungan dan mematikan kreativitas bangsa ${ }^{45}$. Nahdlatul Ulama (NU) menolak liberalisme dan imperialisme dalam segala bentuk dan manifestasinya yang sangat gencar menjajah bangsa lain atas nama pasar bebas dan globalisasi, karena prinsip ini telah digunakan untuk menguasai bangsa lain, sehingga merusak tatanan sosial bangsa lain. Selain itu kehidupan negara dan rakyat menjadi sangat tergantung pada negara besar sehingga mengakibatkan kehidupan rakyat makin sengsara. Nahdlatul Ulama (NU) menolak segala bentuk pengambil alihan aset strategis negara baik sektor ekonomi atau sektor pendidikan dan kebudayaan oleh pihak asing, dengan alasan privatisasi, divestasi atau pun komersialisasi. Demikian juga pengambil alihan aset strategis yang bersifat geografis seperti pencaplokan pulau terpencil sampai soal penggeseran tapal batas Negara Republik Indonesia yang marak belakangan ini adalah merupakan bentuk kolonialisme yang harus ditolak dan

\footnotetext{
${ }^{45}$ Menjaga Kedaulatan sebuah negara merupakan salah satu keputusan Muktamar NU ke-31 di Boyolali, Solo tahun 2004 tentang Taushiyah Muktamar bidang politik internasional. Lihat: PB NU, Hasil-hasil Muktamar XXXI Nahdlatul Ulama (Jakarta: Sekretariat Jenderal PBNU, t.th.), h. 73.
} 
segera dihentikan operasinya, karena tindakan tersebut benar-benar telah melanggar kedaulatan Negara dan menghina martabat rakyat Indonesia secara keseluruhan sebagai sebuah bangsa yang merdeka dan berdaulat. ${ }^{46}$

Perspektif Nahdlatul Ulama (NU) terkait dengan menjaga kedaulatan bangsa dan menjaga keutuhan Negara Kesatuan Republik Indonesia, NU menganjurkan untuk senantiasa memupuk persatuan di tengah masyarakat yang plural dengan cara menanamkan sikap menghargai perbedaan lewat komunikasi dialog dalam konteks mempertahankan kedaulatan bangsa dan negara. Merespons berkembangnya upaya disintegrasi dan perpecahan antara bangsa kita sendiri yang mengakibatkan hilangnya komitmen kebangsaan terhadap integritas dan kesatuan bangsa yang disebabkan oleh dampak negatif globalisasi, kebebasan berpendapat dan ekspresi tanpa batas, yang mengakibatkan munculnya gerakan separatism, radikalisme, konflik ras dan agama yang mengancam kesatuan negara Republik Indonesia, Nahdlatul Ulama (NU) merasa perlu untuk meneguhkan kembali semangat kebangsaan Indonesia dengan menyatakan bahwa Negara Kesatuan Republik Indonesia (NKRI) merupakan bentuk final dari sistem kebangsaan di negara ini. Menurut NU disintegritas bangsa, gerakan separatisme, radikalisme, konflik ras dan agama ini akan menghancurkan tertib dan struktur sosial yang sudah mapan, sehingga merusak relasi sosial, yang kemudian memunculkan rasa saling curiga dan saling membenci yang berujung pada konflik sosial. Dalam situasi sekarang penguatan komitmen kebangsaan tidak bisa dijalankan dengan cara paksaan apalagi kekerasan tetapi perlu strategi kebudayaan baru untuk menata hubungan sosial dan hubungan antar bangsa berdasarkan kesetaraan dan kesukarelaan, sehingga solidaritas sosial dan solidaritas kebangsaan bisa diwujudkan dengan baik penuh kedamaian, oleh karenanya bagi warga Nandliyin bahwa Negara Kesatuan Republik Indonesia (NKRI) merupakan bentuk final dari sistem kebangsaan. ${ }^{47}$

Menanggapi bahaya pencaplokan pulau-pulau terpencil oleh negara lain, menurut KH. Chalid Mawardi (mantan Ketua PBNU yang juga mantan Dubes RI untuk Syria) berpendapat bahwa Nahdlatul Ulama (NU) akan berusaha secara maksimal untuk mempertahankan kedaulatan bangsa dari pencaplokan negara lain, seperti kasus pencaplokan pulau Natuna oleh China, kasus kawasan blok

46Ibid, h. 63.

47 Ibid., h. 62-63. 
Ambalat yang diklaim Malaysia sebagai wilayahnya, menurut Chalid Mawardi untuk menyelesaikan masalah pulau Natuna, blok Ambalat dan Ambalat Timur yang diklaim Malaysia, pemerintah Indonesia sebaiknya menempuh jalur diplomasi bilateral. ${ }^{48}$ Sedangkan menurut Rozi Munir (mantan Ketua PBNU bagian hubungan luar negeri yang juga mantan Menteri BUMN), bahwa Nahdlatul Ulama (NU) mengharapkan agar diutamakan penyelesaian diplomasi atas masalah tersebut. NU telah terbukti sejak dahulu berupaya mempertahankan kedaulatan Negara Kesatuan Republik Indonesia (NKRI) seperti yang dilakukan oleh para sesepuh Nahdlatul Ulama (NU) seperti KH. Wahab Hasbullah, KH Munasir, KH. Sullam, dan lainnya. Dalam hal ini, masih menurut Rozy Munir bahwa Nahdlatul Ulama (NU) akan berusaha secara maksimal berperan aktif untuk mempertahankan kedaulatan bangsa ini dari pencaplokan negara lain, seperti kasus kawasan Ambalat yang diklaim Malaysia sebagai wilayahnya, maka menurut Nahdlatul Ulama (NU) kawasan blok Ambalat harus dipertahankan sebagai bagian dari Negara Kesatuan Republik Indonesia (NKRI) dengan cara menjalin komunikasi antar ormas dan ulama, baik di Indonesia maupun dari Malaysia. Namun demikian, juga mengingatkan bahwa

\footnotetext{
48Menurut Chalid Mawardi: "Dengan menimbang situasi nasional, dukungan ekonomi dan kekuatannya, Indonesia perlu menghindari penggunaan kekuatan militer dan Mahkamah International dalam penyelesaian blok Ambalat dan Ambalat Timur yang diklaim Malaysia. Dengan segala kelemahan yang dimilikinya, Indonesia lebih tepat menggunakan cara-cara diplomasi. Dengan situasi yang sedang dihadapi Indonesia dan teknologi militer yang tidak imbang, jangan pernah berpikir untuk perang dengan pihak Malaysia, dengan diplomasi bilateral, Indonesia harus mempertahankan haknya atas Ambalat yang sangat ditentukan oleh kemampuan Indonesia dalam menunjukkan bukti-bukti legitimasinya. Dalam logika hubungan antar bangsa, pihak yang lebih dahulu mengelola pulau yang masih dianggap asing biasanya disebut sebagai pemiliknya. Jadi pengelolaan negara tertentu secara lebih awal atas kepulauan yang disengketakan akan sangat menguatkan status kepemilikan wilayah tersebut. Jadi tergantung bendera siapa yang berkibar di sana, siapa yang lebih dulu mendiaminya? Dalam penyelesaian ini tidak cukup hanya dengan bukti bahwa secara de facto, negara Republik Indonesia lebih dahulu mengelola blok Ambalat dan Ambalat Timur, pemilihan media penyelesaiannya juga menentukan. Apakah memilih diplomasi bilateral ataukah Mahkamah Internasional? Kalau Indonesia memilih Mahkamah Internasional, sangat kecil kemungkinan Indonesia akan menang. Sebab, biayanya tidak kecil, bisa-bisa dana APBN tersedot ke sana semua. Lain halnya bagi Malaysia, melalui jalur Mahkamah Internasional, ia akan diuntungkan, dia punya uang dan kemungkinan besar juga akan dibantu negara-negara persemakmuran yang lain. Saya menganjurkan kepada Pemerintah Indonesia untuk memilih jalan diplomasi bilateral. Dengan jalan bilateral, maka lebih mungkin diperoleh hasil penyelesaian yang adil. Indonesia harus menyiapkan diri dalam diplomasi bilateral, buktikan bahwa memang blokAmbalat dan Ambalat Timur itu merupakan kelanjutan alamiah dari daratan Kalimantan Timur, dan bukan kelanjutan alamiah dari daratan Sabah. Jadi ambil jalan diplomasi, jangan jalan perang, persenjataan Malaysia lebih canggih dibanding Indonesia, apalagi dengan dukungan Negara-negara persemakmuran Inggris, kecuali Indonesia bisa ajak Singapura untuk menghadapi Malaysia”. Lihat juga: NU Online, Warta, 10 Maret 2005. Lihat juga: PBNU, Program Dasar Pengembangan Lima Tahun Nahdlatul Ulama: Keputusan Muktamar NU XXVI, (Jakarta: Lajnah Ta'lif waal-Nars PBNU,1979), h. 51.
} 
konflik ini sudah melibatkan pihak ketiga, yaitu para perusahaan minyak yang mengeksplorasi kawasan tersebut, oleh karena itulah kedua belah pihak harus berhati-hati agar tidak dimanfaatkan oleh pihak ketiga demi kepentingan mereka untuk memperkaya diri. Berbeda menurut Maksum Zuber mantan Koordinator Barisan Muda Nahdlatul Ulama (BMNU) bahwa dia siap mengamankan kepulauan Indonesia walaupun harus mengerahkan massa, dan dia menghimbau agar pemerintah dan DPR mengambil langkah tegas dengan melayangkan sikap protes ke Kedubes Malaysia di Jakarta untuk menghentikan pencaplokan kawasan blok Ambalat ini. ${ }^{49}$

Prinsip NU (Nahdlatul Ulama) tentang mempertahankan kedaulatan dan keutuhan NKRI adalah prinsip utama bagi umat Islam untuk menjaga keutuhan negara Indonesia pada saat ini. Hal ini semakin penting karena Indonesia tengah menghadapi persoalan serius yaitu kemungkinan terjadinya disintegrasi nasional, dimana muncul adanya keinginan dari beberapa daerah untuk memisahkan dari Negara Kesatuan Republik Indonesia (NKRI), menurut KH. Syaifuddin (Wakil Katib Syuriah NU Jawa Timur) pemerintah perlu berupaya untuk penyempurnaan Undang-Undang Otonomi Daerah sehingga aturan tersebut nantinya tidak mengilhami suatu daerah untuk memisahkan diri dari negara nasional dan aturan tersebut dibuat harus didasari atas semangat menjaga kedaulatan, keutuhan NKRI serta untuk memajukan kesejahteraan masyarakat. ${ }^{50}$ Oleh karenanya menurut $\mathrm{NU}$ bahwa konsistensi menjaga

\footnotetext{
${ }^{49}$ Menurut Maksum Zuber, menyatakan bahwa dirinya siap mengerahkan massa untuk menggalang relawan guna menghadapi konfrontasi dengan Malaysia, termasuk soal konflik blok Ambalat demi mempertahankan Negara Kesatuan Republik Indonesia (NKRI). Menurutnya, sikap Malaysia yang suka memancing-mancing konfrontasi dinilai sudah keterlaluan, bahkan bukan kali ini saja Malaysia melanggar wilayah kedaulatan NKRI, mereka bahkan sering memprovokasi munculnya konflik dari pencaplokan pulau-pulau kecil yang masih menjadi wilayah kesatuan negara Republik Indonesia. Maksum Zuber menginginkan agar pemerintah dan DPR mengambil langkah tegas dengan melayangkan sikap protes ke Kedubes Malaysia di Jakarta. Lihat, A. Zuhdi Mukhdlor, NU dan Politik (NU and Politics) ..., h. 36. Lihat juga: PBNU, Program Dasar Pengembangan Lima Tahun Nahdlatul Ulama: Keputusan Muktamar NU XXVI (Jakarta: Lajnah Ta'lif wa al-Nars PBNU, 1979), h.37. Lihat juga: Zudi Setiawan, "Pemikiran dan Kebijakan Nahdlatul Ulama dalam Menjaga Kedaulatan Wilayah Negara Kesatuan Republik Indonesia pada Era Reformasi (1998-2009)", Jurnal Ilmu Politik Hubungan Internasional, Spektrum, Vol. 7, No. 1, Januari 2010, h.17.

${ }^{50} \mathrm{Hal}$ ini senada dengan pendapat yang disampaikan oleh K.H. Syaifudin wakil katib Syuriah PWNU Jawa Timur yang juga mantan anggota Fraksi Kebangkitan Bangsa DPRD Propinsi Jawa Timur, Lihat; Ali Maschan Moesa, Nasionalisme Kiai: Konstruksi Sosial Berbasis Agama, LKiS, Yogyakarta, 2007, h. 178. Dan Hal ini sebagaimana yang disampaikan oleh Sekretaris Lajnah Bahtsul Masail PWNU JawaTimur yang juga Ketua Dewan Syuro Pengurus Anak Cabang (PAC) Partai Kebangkitan Bangsa Kecamatan Benowo Surabaya K.H. Syahid, beliau mengatakan bahwa gerakan sparatis di Indonesia seperti GAM
} 
persatuan untuk memperkokoh integritas bangsa, keutuhan NKRI dan Pancasila adalah hal yang mendasar bagi rakyat Indonesia secara umum dan bagi warga nahdliyyin secara husus. Karena keutuhan NKRI dan falsafah bangsa "Pancasila" selain telah terbukti mampu menjadi perekat bangsa sejak kemerdekaan hingga sekarang, juga mampu menjadi wadah dakwah Islam Nusantara secara luas. Pertumbuhan muslim di kawasan-kawasan mayoritas non muslim juga semakin meningkat. Namun demikian, di tengah perjalanan sejarah tantangan disintegrasi bangsa terkadang bermunculan, bahkan wacana mendirikan negara di dalam negara terus mengemuka. Sebab itu, internalisasi nilai-nilai kebangsaan, khususnya terkait NKRI dan Pancasila sebagai upaya final dalam kehidupan berbangsa dan bernegara merupakan keharusan. 51

Berkenaan dengan itu perlu disadari, bahwa penerimaan Pancasila sebagai falsafah kehidupan berbangsa dan bernegara telah sesuai dengan spirit "Piagam Madinah" yang digagas oleh Rasulullah, yang berhasil menyatukan masyarakat yang plural dalam satu kesatuan negeri Madinah. ${ }^{52}$ Dari Piagam

adalah sisi buruk dari bangsa Indonesia. Lihat, Syaifuddin Zuhri, K.H., Sejarah Kebangkitan Islam dan Perkembangannya di Indonesia (Bandung: Al Ma'arif, 1979) h. 458-460.

51Einar Martahan Sitompul, NU dan Pancasila (Yogyakarta: LKiS, 2010), h. 53.

52Sebagaimana diriwayatkan Ibn Ishaq dalam al-Sirah al-Nabawiyah (II/126-129) karya Ibn Hisyam, Piagam Madinah diantaranya menyatakan:

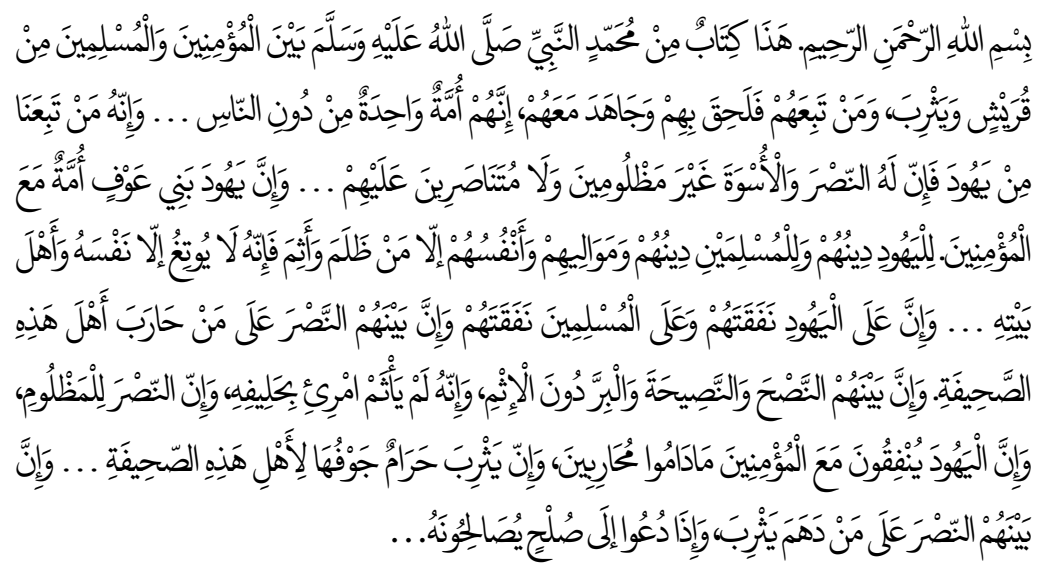

Semua ini berdasar dari hasil Keputusan Baḥth al-Masāil Mawḍu'ìyyah PWNU Jawa Timur tentang "Islam Nusantara" di Universitas Negeri Malang pada tanggal 13 Februari 2016, yang reverensinya diambil dari kitab: a) al-Hawi al-Kabir, XIV/330. b) Risālah al-Qushairiyyah, I/103. (c). Ihyā' 'Ulūm al-Dīn, II/212. d) al-Majālis al-Saniyyah, 87. 
Madinah dapat diambil spirit, bahwa Nabi Muhammad menyatukan warga yang multi etnis dan multi agama menjadi ummah wähidah (satu kesatuan bangsa). Semua warga punya kedudukan yang sederajat, sama-sama berhak mendapatkan jaminan keamanan, melakukan aktivitas ekonomi, mengaktualisasikan agama, sama-sama berkewajiban untuk saling memberi nasehat dan berbuat kebaikan, menjaga keamanan serta integritas Madinah sebagai satu kesatuan negeri menghadapi ancaman dari luar. ${ }^{53}$

Oleh karenanya sebagaimana dalam keputusan Keputusan Baḥth al-Masāil Mawdu'iyyah PWNU Jawa Timur Tentang "Islam Nusantara" di Universitas Negeri Malang pada tanggal 13 Februari 2016, selain anjuran untuk menjaga kedaulatan bangsa dalam bingkai NKRI juga menganjurkan untuk memupuk persatuan di tengah masyarakat yang plural perlu ditanamkan sikap menghargai perbedaan dan menjaga hak antar sesama, di antaranya dengan:

a. Menghargai ajaran agama lain.

b. Melestarikan budaya dari suku dan agama apa pun selama tidak bertentangan dengan syariat.

c. Mengapresiasi kebaikan/kelebihan orang lain dan mengakui kekurangan diri sendiri.

d. Menghindari caci-maki terhadap orang lain karena alasan perbedaan.

e. Menghindari anggapan menjadi orang yang paling baik dan menganggap orang lain tidak baik, sehingga mengabaikan kewajiban berbuat baik.

f. Membiasakan berbuat kebajikan terhadap siapapun.

g. Memprioritaskan penanaman nilai-nilai agama secara utuh dan mendalam di lingkungan internal Ahl al-Sunnah wa'l-Jamä’ah.54

53Mahfud MD, Gus Dur: Islam, Politik dan Kebangsaan (Yogyakarta: LKiS, 2010), h. 26.

${ }^{54} \mathrm{Hal}$ ini berdasar atas perintah Allah dan tuntunan Nabi Muhammad yang dijelaskan dalam Hadis, reverensi yang ambil dalam Keputusan Bahth al-Masāil Mawdu'tyyah PWNU Jawa Timur tentang "Islam Nusantara" di Universitas Negeri Malang pada tanggal 13 Februari 2016 adalah:

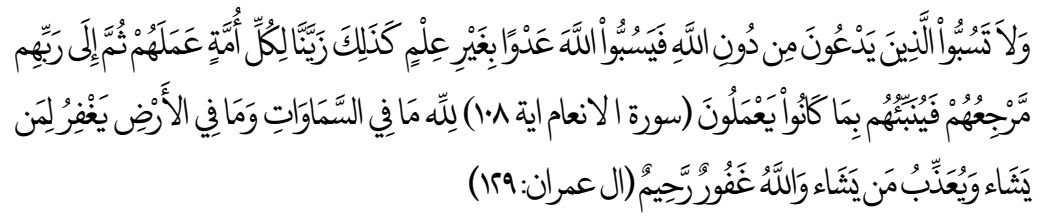




\section{Kesimpulan}

Nahdlatul Ulama (NU) pimpinan Hadhratus Syaikh KH. Hasyim Asy'ari sangat menjunjung tinggi nilai-nilai kebangsaan, nasionalisme yang berdasar atas syaria'at Islam alā Ahlu al-sunnah wal al-jamä'ah. Sebelum negara Republik Indonesia merdeka, para pemuda di berbagai daerah mendirikan organisasi bersifat kedaerahan, seperti Jong Cilebes, Pemuda Betawi, Jong Java, Jong Ambon, Jong Sumatera, dan sebagainya, akan tetapi Kiai-Kiai NU justru mendirikan organisasi pemuda bersifat nasionalis. Dari rahim NU juga lahir laskar-laskar perjuangan fisik, di kalangan pemuda muncul laskar-laskar hizbullāh (Tentara Allah) dengan panglimanya KH. Zainul Arifin seorang pemuda kelahiran Barus Sumatera Utara 1909, dan di kalangan orang tua sabïlillāh (Jalan menuju Allah) yang di komandoi oleh KH. Masykur. Perjuangan jihad laskar-laskar Nahdlatul Ulama (NU) dalam mengusir penjajah Belanda sebenarnya adalah tuntunan ajaran agama Islam yang harus dilaksanakan setiap umat-Nya sebagai bentuk manivestasi rasa syukur terhadap Allah SWT yang maha kuasa. Jihad yang dilakukan oleh laskar-laskar Nahdlatul Ulama (NU) ialah jihad membela tanah air, sebagai bentuk cinta tanah air (hubb alwațan) yang dimaknai sebagai jihad fi sabīlillāh. Karena upaya mempertahankan dan menegakkan negara Republik Indonesia dalam pandangan hukum Islam merupakan bagian dari kewajiban agama yang harus dijalankan umat Islam. Jihad sebagai satu amalan besar dan penting dalam Islam dengan keutamaannya yang sangat banyak sekali tentunya menjadi kewajiban seorang muslim untuk melaksanakanya bila suatu saat diserang oleh orang kafir.

Perjuangan yang dilakukan oleh Nahdlatul Ulama dengan upaya yang kuat menggerakan para ulama, santri dan umatnya untuk bangkit menghimpun

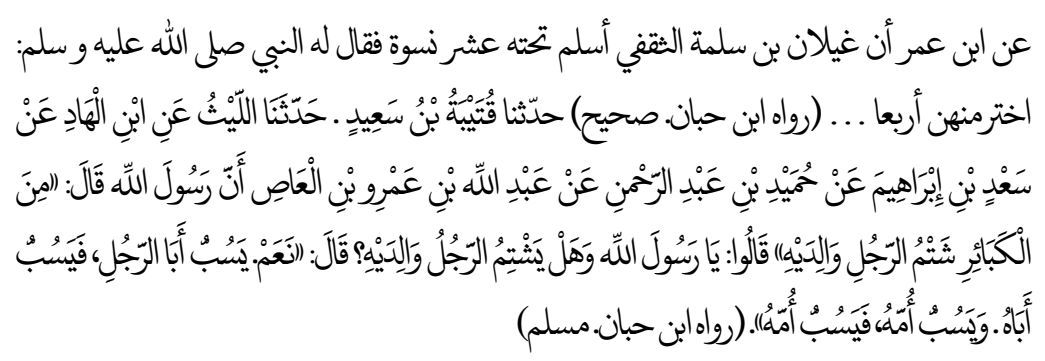


kekuatan melawan pemerintahan asing yang dianggap kafir, merupakan bukti sejarah yang tidak dapat dipungkiri. Bahkan menurut hitungan rasional kemerdekaan negara Indonesia ini tidak akan pernah terwujud, mengingat rakyat Indoneisa pada saat itu merupakan rakyat yang miskin, serba kekurangan, untuk makan saja masih sulit akibat kejamnya penjajahan, demikian juga minimnya persenjataan yang dimiliki oleh pasukan dan relawan pejuang rakyat kita, apabila dibandingkan dengan persenjataan yang dimiliki oleh penjajah Belanda. Akan tetapi berkat motivasi para ulama kita termasuknya adalah ulama-ulama NU yang berupaya mentranspormasi gerakan-gerakan yang bersifat spontanitas kepada mekanik atau organik dari doa dan wiridwirid yang diberikan oleh ulama-ulama NU (bisa berupa asmā', hizb, dhikir, șalawat dan lain sebagainya) menjadi sebuah sugesti besar pensakralan dan kekuatan besar untuk melawan peperangan melawan penjajah, maka dengan sugesti yang kuat ini perjuangan para ulama bisa menghantarkan kesebuah kemerdekaan berkat rahmat Allah SWT.

Prinsip Nahdlatul Ulama (NU) terkait dengan menjaga kedaulatan bangsa dan menjaga keutuhan Negara Kesatuan Republik Indonesia, NU menganjurkan untuk senantiasa memupuk persatuan di tengah masyarakat yang plural dengan cara menanamkan sikap menghargai perbedaan lewat komunikasi dialog dalam konteks mempertahankan kedaulatan bangsa dan negara. Merespon berkembangnya upaya disintegrasi dan perpecahan antara bangsa kita sendiri yang mengakibatkan hilangnya komitmen kebangsaan terhadap integritas dan kesatuan bangsa yang disebabkan oleh dampak negatif globalisasi, kebebasan berpendapat dan ekspresi tanpa batas, yang mengakibatkan munculnya gerakan separatism, radikalisme, konflik ras dan agama yang mengancam kesatuan negara Republik Indonesia, NU merasa perlu untuk meneguhkan kembali semangat kebangsaan Indonesia dengan menyatakan bahwa Negara Kesatuan Republik Indonesia (NKRI) merupakan bentuk final dari sistem kebangsaan di negara ini.[w] 


\section{BIBLIOGRAFI}

Abdullah, Taufik, Ilmu Sejarah dan Historiografi; Arah dan Perspektif, Jakarta: Gramedia, 1984.

Abu Syauk, Ahmad Ibrahim, Tārīkh Harakah al-Ișlāh wa al-Irshād wa Shaikh alIrshādiyyīn Ahmad Muhammad al-Surkatiy fi Indonesia (History of al-Irsyad Islamic Movement leader Ahmad al-Syurkati in Indonesia), Kuala Lumpur: publikasi bersama antara Research Centre International Islamic University Malaysia dan Dār al-Fajr Malaysia, 2000.

Adnan, M. Mas'ud, Resolusi Jihad dalam Peristiwa 10 November, Surabaya: Jawa Pos, 1999.

Amin, Samsul Munir, Karomah Para Kiai, Yogyakarta: LKIS. 2008.

Amrullah, Abdul Malik Karim (HAMKA), Sejarah Umat Islam, Jakarta: Bulan Bintang, 1981.

Anam, Choirul, Pertumbuhan dan Perkembangan NU, Surabaya: Bisma Satu Press, 1998.

Azra, Azyumardi, Islam Reformis, Jakarta: Raja Grafindo Persada,1999.

, Jaringan Ulama Timur Tengah dan Kepulauan Nusantara Abad XVII \& XVIII Akar Pembaruan Islam Indonesia, Jakarta: Kencana Press, 2004.

Bikten, Robert Bag, Qualitative Research For Education; An Introduction to Theory and Methods, Boston: Allyn and Bocon, 1982.

Bizawie, Zainul Milal, Laskar Ulama dan Santrinya \& Resolusi Jihad; Garda Depan Menegakkan Indonesia 1945-1949, Tangerang: Pustaka Compass, 1998.

Braginksy, Yang Indah, Berfaedah dan Sempurna: Sejarah Sastra Melayu dalam Abad 7-19, Jakarta: INIS Press, 1998.

Brinessen, Martin Van, "The 28 th Congres of the NU: Power And Struggle And Social Concerns", Archipel Journal, Paris , 1991. “Indonesia's Ulama And Politics”, Prisma, Vol. 49, LP3ES, Jakarta, 1990. NU, Tradisi, Relasi-Relasi Kuasa, Pencarian Wacana Baru, Yogyakarta: LKiS, 1994.

Budiardjo, Miriam, Dasar-dasar Ilmu Politik, Jakarta: Gramedia Pustaka Utama, 2001. 
Burhanuddin, Jajat, Ulama dan Kekuasaan: Pergumulan Elite Muslim dalam Sejarah Indonesia, Bandung: Mizan, 2012.

Burns, Peter, Revelation and Revolution: Natsir and the Pancasila, Townsville: Committee of South-East Asian Studies, James Cook University of North Queensland, 1981.

Dahlan, Ahmad, Sejarah Melayu, Jakarta: Gramedia, 2014.

Feillard, Andree, NU Vis a Vis Negara; Pencarian Isi, Bentuk dan Makna, Yogyakarta: LKiS, 1994.

Gostchalck, Louis, Mengerti Sejarah, terj. Nugroho Notosusanto, Jakarta: Universitas Indonesia Press, 1983.

Hakim, Lukman , Perlawanan Islam Kultural: Relasi Asosiatif Pertumbuhan Civil Society dan Doktrin Aswaja NU, Surabaya: Pustaka Eureka Berger Peter L, 1991.

Kebangkitan Agama Menantang Politik Dunia, Yogyakarta: Ar-Ruzz Hartono Press, 2003.

Hasan AZ, Perlawanan dari Tanah Pengasingan: Kiai Abbas, Pesantren Buntet dan Bela Negara, Yogyakarta: LKiS, 2014.

Hatta, Mohammad, Sekitar Proklamasi 17 Agustus 1945, Jakarta: Tintamas Press, 1969.

Henri, Chambert Loir, Naik Haji di Masa Silam Kisah-kisah Orang Indonesia Naik Haji 1482-1964, Jakarta: KPG Press, 2013.

Iskandar, Teuku, Kesusasteraan Klasik Melayu Sepanjang Abad, Jakarta: Penerbit LIBRA, 1996.

Kasid, Aminudin, Pengantar Ilmu Sejarah, Semarang: UNESS Press, 2015.

Khuluq, Lathiful, Fajar Kebangunan Ulama, Biografi Kiyai Hasyim Asy'ari, Yogjakarta: LKiS, 2000.

Kusuma, A.B., Lahirnya Undang-Undang Dasar, Jakarta: Badan Penerbit Fakultas Hukum Universitas Indonesia, 2004.

Laffan, Michael Francis, Islamic Nationhood and Colonial Indonesia; The Umma below the Winds, London: Routledge Curzon, 2003.

Marijan, Kacung, Quo Vadis NU Setelah Kembali ke Khittah 1926, Jakarta: Penerbit Erlangga, 1992.

Masyhuri, Abdul Azis H., Al-Maghfurlah KH. Bishri Syansuri: Cita-cita dan Pengabdiannya, Surabaya: Al-Ikhlas Press, 1983. 
NU dari Masa ke Masa, Surabaya: Al-Ikhlas Press, 1983.

Moesa, Ali Maschan, Nasionalisme Kiai: Konstruksi Sosial Berbasis Agama, Yogyakarta: LKiS, 2007.

Kiai Politik, Surabaya: LEPKISS, 1999.

Muhaimin, Abdul Ghoffir, "Pesantren and Tarekat in the Modern Era: An Account of the Transmission of Traditional Islam in Java", Jurnal Studia Islamika, Vol. 4, November.1, 1997, h. 17-25.

The Islamic Tradition of Cirebon: Ibadat and Adat among Javanese Muslim, Canberra: ANU Press, 2006.

Mukhdlor, Zuhdi A, NU dan Politik, Yogyakarta: PT. Gunung Jati dan Pondok Pesantren al-Munawwir Krapyak, 1986.

Mustafa, Mustari, Agama dan Bayang-bayang Etis, Syeikh Yusuf Al-Makassari, Yogyakarta: LKiS, 2011.

Nagazumi, Akira, Bangkitnya Nasionalisme Indonesia Budi Utomo 1908-1918 (The rise of nationalism Indonesia Budi Utomo 1908-1918), Jakarta: Pustaka Utama Grafiti, 1989.

Noer, Deliar, Gerakan Moderen Islam di Indonesia, Jakarta: LP3ES 1994.

Notosusanto, Nugroho, Teori Sejarah dan Perannya dalam Rangka Study Sejarah, Jakarta: UI Press, 1978.

Nurlira Goncing, "Politik Nahdlatul Ulama dan Orde Baru", The Politics: Jurnal Magister Ilmu Politik UNHAS, Vol. 1, No.1,2015, h. 67-68.

PBNU, Pokok-pokok Pikiran tentang Pemulihan Khittah NU 1926, Jakarta: Lajnah wa al-Nars PBNU, 1983.

PBNU, Program Dasar Pengembangan Lima Tahun Nahdlatul Ulama; Keputusan Muktamar NU XXVI, Jakarta: Lajnah Ta'lif wa al-Nars PBNU, 1979.

Perwiranegara, Alamsjah Ratu, Islam dan Pembangunan Politik di Indonesia, Jakarta: CV Haji Masagung, 1987.

Raffles, Thomas Stamford, The History of Java, Jakarta: Narasi Press 1976.

Rifa'i, Muhammad, K.H. Wahab Hasbullah Biografi Singkat 1888-1971, Yogyakarta: Garasi House of Book. 2010.

Shihab, Quraish, Wawasan Al-Qur'an, Bandung: Mizan, 2013.

Siddiq, Achmad KH, Islam, Pancasila dan Ukhuwah Islamiyyah, Jakarta: Lajnah wa al-Nars PBNU dan Penerbit Sumber Barokah, 1985. 
Sihabuddin, Ahmad, Telaah Kritis Atas Doktrin Faham Salafi-Wahabi, Yogyakarta: UII Press, 2011.

Sukidi Mulyadi, "Violence under The Banner of Religion: The Case of Laskar Jihad and Laskar Kristus," Jurnal Studia Islamika, Vol. 10, No. 1, 2003.

Surakhmad, Winarno, Pengantar Penelitian Ilmiah, Dasar Metode dan Tehnik, Bandung: Tarsito Press, 1982.

Suroso, Nahdlatul Ulama, Eksistensi Peran dan Prospeknya, Malang: LP Ma'arif Malang, 1987.

Suryanegara, Ahmad Mansur, Api Sejarah: Mahakarya Perjuangan Ulama dan Santri dalam Menegakkan Negara Kesatuan Republik Indonesia, Bandung: Penerbit Salmadani, 1433/2012.

Menemukan Sejarah: Wacana Pergerakan Islam di Indonesia, Bandung: Mizan, 1996.

Syafi'i Ma'arif, Ahmad, Islam dan Politik, Jakarta: Insani Press, 1996.

Vehide, Sukran, Biografi Intelektual Badiuzzaman Said Nursi, Transformasi Dinasti Usmani Menjadi Republik Turki,Jakarta: Anatolia Press, 2007.

Vlekke, Bernard H.M., Nusantara Sejarah Indonesia, Jakarta: Kepustakaan Populer Gramedia, 2010.

Wahid, Abdul, Peranan Pondok Pesantren Buntet Cirebon bagi Kemajuan Lingkungan Pendidikan di Sekitar 1958-2009, Semarang: Universitas Negeri Semarang Press, 2012.

Yatim, Badri, Sejarah Peradaban Islam: Dirasah Islamiyah II, Jakarta: Rajawali Pers, 1991.

Zubair. "Jihad dan Kemerdekaan: Studi atas Naskah Nasihatul Muslimin wa Tazkiratul Mu'minin", Jurnal Puslitbang Lektur Keagamaan Badan Litbang dan Diklat Kementrian Agama RI, Vol. 9. No. 2, November 2011.

Zudi Setiawan, "Pemikiran dan Kebijakan Nahdlatul Ulama dalam Menjaga Kedaulatan Wilayah Negara Kesatuan Republik Indonesia pada Era Reformasi (1998-2009)", Jurnal Ilmu Politik Hubungan Internasional, Spektrum, Vol. 7, No. 1, Januari 2010.

Zuhri, Syaifuddin, Sejarah Kebangkitan Islam dan Perkembangannya di Indonesia, Bandung: Al-Ma'arif, 1979. 
